\title{
Direct and indirect predictions of enteric methane daily production, yield, and intensity per unit of milk and cheese, from fatty acids and milk Fourier-transform infrared spectra
}

\author{
Giovanni Bittante and Claudio Cipolat-Gotet ${ }^{1}$ \\ Department of Agronomy, Food, Natural Resources, Animals and Environment, University of Padova (Padua), \\ viale dell'Università 16-35020 Legnaro (PD), Italy
}

\section{ABSTRACT}

Mitigating the dairy chain's contribution to climate change requires cheap, rapid methods of predicting enteric $\mathrm{CH}_{4}$ emissions (EME) of dairy cows in the field. Such methods may also be useful for genetically improving cows to reduce EME. Our objective was to evaluate different procedures for predicting EME traits from infrared spectra of milk samples taken at routine milk recording of cows. As a reference method, we used EME traits estimated from published equations developed from a meta-analysis of data from respiration chambers through analysis of various fatty acids in milk fat by gas chromatography $\left(\mathrm{FA}_{\mathrm{GC}}\right)$. We analyzed individual milk samples of 1,150 Brown Swiss cows from 85 farms operating different dairy systems (from very traditional to modern), and obtained the cheese yields of individual model cheeses from these samples. We also obtained Fourier-transform infrared absorbance spectra on 1,060 wavelengths $(5,000$ to 930 waves $/ \mathrm{cm})$ from the same samples. Five reference enteric $\mathrm{CH}_{4}$ traits were calculated: $\mathrm{CH}_{4}$ yield $\left(\mathrm{CH}_{4} / \mathrm{DMI}, \mathrm{g} / \mathrm{kg}\right)$ per unit of dry matter intake (DMI), and $\mathrm{CH}_{4}$ intensity $\left(\mathrm{CH}_{4} / \mathrm{CM}\right.$, g/ $\mathrm{kg}$ ) per unit of corrected milk $(\mathrm{CM})$ from the $\mathrm{FA}_{\mathrm{GC}}$ profiles; $\mathrm{CH}_{4}$ intensity per unit of fresh cheese $\left(\mathrm{CH}_{4} /\right.$ $\left.\mathrm{CY}_{\text {CURD }}, \mathrm{g} / \mathrm{kg}\right)$ and cheese solids $\left(\mathrm{CH}_{4} / \mathrm{CY}_{\text {SOLIDS }}, \mathrm{g} / \mathrm{kg}\right)$ from individual cheese yields $(\mathrm{CY})$; and daily $\mathrm{CH}_{4}$ production $\left(\mathrm{dCH}_{4}, \mathrm{~g} / \mathrm{d}\right)$. Direct infrared (IR) calibrations were obtained by BayesB modeling; the determination coefficients of cross-validation varied from 0.36 for $\mathrm{dCH}_{4}$ to 0.57 for $\mathrm{CH}_{4} / \mathrm{CM}$, and were similar to the coefficient of determination values of the equations based on $\mathrm{FA}_{\mathrm{GC}}$ used as the reference method (0.47 for $\mathrm{CH}_{4}$ / DMI and 0.54 for $\mathrm{CH}_{4} / \mathrm{CM}$ ). The models allowed us to select the most informative wavelengths for each EME trait and to infer the milk chemical features underlying the predictions. Aside from the 5 direct infrared

Received December 14, 2017.

Accepted April 17, 2018.

${ }^{1}$ Corresponding author: claudio.cipolatgotet@unipr.it prediction calibrations, we tested another 8 indirect prediction models. Using IR-predicted informative fatty acids $\left(\mathrm{FA}_{\mathrm{IR}}\right)$ instead of $\mathrm{FA}_{\mathrm{GC}}$, we were able to obtain indirect predictions with about the same precision (correlation with reference values) as direct IR predictions of $\mathrm{CH}_{4} / \mathrm{DMI}$ (0.78 vs. 0.76 , respectively) and $\mathrm{CH}_{4} / \mathrm{CM}$ (0.82 vs. 0.83). The indirect EME predictions based on IR-predicted $\mathrm{CY}$ were less precise than the direct IR predictions of both $\mathrm{CH}_{4} / \mathrm{CY}_{\mathrm{CURD}}$ (0.67 vs. 0.81 ) and $\mathrm{CH}_{4} / \mathrm{CY}_{\text {SOLIDS }}(0.62$ vs. 0.78$)$. Four indirect $\mathrm{dCH}_{4}$ predictions were obtained by multiplying the measured or IR-predicted daily CM production by the direct or indirect $\mathrm{CH}_{4} / \mathrm{CM}$. Combining recorded daily $\mathrm{CM}$ and predicted $\mathrm{CH}_{4} / \mathrm{CM}$ greatly increased precision over direct $\mathrm{dCH}_{4}$ predictions $(0.96-0.96$ vs. $0.68)$. The estimates obtained from the majority of direct and indirect IR-based prediction models exhibited herd and individual cow variability and effects of the main sources of variation (dairy system, parity, days in milk) similar to the reference data. Some rapid, cheap, direct and indirect IR prediction models appear to be useful for monitoring EME in the field and possibly for genetic/genomic selection, but future studies directly measuring $\mathrm{CH}_{4}$ with different breeds and dairy systems are needed to validate our findings.

Key words: mid-infrared, near-infrared, ecological footprint, greenhouse gas, global warming

\section{INTRODUCTION}

Simple, noninvasive, cheap methods are needed that may be used with individual dairy cows at the population level to monitor herds for enteric $\mathrm{CH}_{4}$ emissions (EME) and possibly to reduce them through genetic improvement of dairy cattle. Some studies have shown that the phenotypic variability of EME has a genetic basis (Pryce and Bell, 2017), but a major problem in genetically evaluating animals lies in the fact that the gold standard for accurate, precise EME quantification (i.e., the respiration chamber) is an expensive tool that can be used only in an artificial environment and on few animals, which is a problem in a genetic approach, 
and is available only in some research centers (de Haas et al., 2017).

Simpler, direct methods involve taking samples of the air near the cows' nostrils and mouths, and from these estimating the $\mathrm{CH}_{4}$ eructated from the rumen and, in part, that emitted from the intestine through the lungs, which represents about 6 to $14 \%$ of total EME (Immig, 1996). Theoretically more precise and accurate methods involve the continuous release of a gas tracer in the rumen at a known rate, which is used as a reference for calculating $\mathrm{CH}_{4}$ emission (Beauchemin et al., 2012), often using instruments mounted on the back of the cows. These methods are, in any case, expensive and involve ethical/animal welfare issues. The most practical methods, easy to use at the farm level, involve placing sampling instruments in the automatic milking systems or the automatic concentrate feeders (de Haas et al., 2017). These methods can sample the air at every visit of the cow (i.e., several times per day), but it is not clear to what extent the $\mathrm{CH}_{4}$ emitted during milking or feeding is representative of the complete daily balance. Lastly, detectors that can function at a distance (laser, infrared) can be used during different phases of the cows' daily routine, but technicians are needed to operate them (Chagunda and Yan, 2011). The methods that do not use rumen tracers rely on measurement of the ratio between $\mathrm{CH}_{4}$ and $\mathrm{CO}_{2}$ in the air sample to predict daily $\mathrm{CH}_{4}$ release on the basis of theoretical $\mathrm{CO}_{2}$ emission predicted from one or more cow's traits (BW, milk yield, DMI, and so on; Madsen et al., 2010). These methods are less accurate and precise than respiration chambers, as the various EME patterns according to diet differ from the gold standard (Hammond et al., 2016) and from each other (Hristov et al., 2016), so their use is controversial (Wu et al., 2018).

Among the indirect methods based on genetic correlations with other traits, the favorable relation between EME and feed efficiency is very interesting (Basarab et al., 2013). However, the problem here is how to measure the feed DMI of individual animals at the population level. Interest is also growing in other indirect predictions of EME traits, as reviewed by Negussie et al. (2017). Among the more promising methods, studies have shown that the fatty acid (FA) profile of milk reflects microbial activity in the rumen, and therefore, EME, as reviewed by van Gastelen and Dijkstra (2016). Here, too, the gold standard for FA analysis [i.e., gas chromatography $\left(\mathbf{F A}_{\mathrm{GC}}\right)$ ], despite being much simpler and cheaper than EME analyzed by respiration chambers, cannot be easily used in the context of routine milk recording schemes.

Infrared (IR) spectrometry has been widely used for predicting FA (FA $\mathbf{A}_{\mathbf{I R}}$ ) in milk (Rutten et al., 2009;
Soyeurt et al., 2011; Ferrand-Calmels et al., 2014) and meat (Cecchinato et al., 2012), with interesting results. However, the major limitation is that, despite improvements in prediction methods (Eskildsen et al., 2014; Fleming et al., 2017), IR spectrometry yields good results for those milk FA with the highest concentrations, whereas some of the most interesting FA for predicting EME are those derived from microbial activity in the rumen, which are found in low concentrations (van Gastelen and Dijkstra, 2016). An alternative is to use IR spectrometry for direct prediction of EME traits from milk spectra, which is the most attractive option as IR spectra are routinely obtained from almost all individual milk samples processed within milk recording schemes and from bulk farm samples taken for milk quality pricing systems. In a preliminary study carried out on a very small number of cows, Dehareng et al. (2012) obtained promising results using Fouriertransform infrared (FTIR) spectra to predict the daily $\mathrm{CH}_{4}$ production $\left(\mathbf{d C H}_{\mathbf{4}}, \mathrm{g} / \mathrm{d}\right)$ of individual cows, and $\mathrm{CH}_{4}$ intensity $\left(\mathrm{CH}_{4} / \mathrm{CM}, \mathrm{g} / \mathrm{kg}\right)$ expressed per unit of fat- and protein-corrected milk (CM) produced. Later, the same research group published promising results from a study of a larger number of cows (Vanlierde et al., 2015, 2016; Vanrobays et al., 2016), although Shetty et al. (2017), using similar approaches, obtained unsatisfactory results.

As various EME traits have been analyzed in different studies (van Gastelen and Dijkstra, 2016; de Haas et al., 2017), but have not been compared in large surveys, in a recent study we used the method of van Lingen et al. (2014) based on selected $\mathrm{FA}_{\mathrm{GC}}$ to estimate $\mathrm{CH}_{4} / \mathrm{CM}$ and $\mathrm{CH}_{4}$ yield per unit of DMI $\left(\mathrm{CH}_{4} / \mathrm{DMI}\right)$, and to study the effect of dairy system, herd within dairy system, and parity and lactation stage of dairy cows (Bittante et al., 2018). In addition, we calculated $\mathrm{dCH}_{4}$ by multiplying daily $\mathrm{CM}$ yield (dCMY, $\mathrm{kg} / \mathrm{d}$ ) by $\mathrm{CH}_{4} / \mathrm{CM}$, and as no study has previously reported this, we also estimated $\mathrm{CH}_{4}$ intensity per kilogram of fresh cheese $\left(\mathbf{C H}_{4} / \mathbf{C Y}_{\mathbf{C U R D}}, \mathrm{g} / \mathrm{kg}\right)$ and cheese solids $\left(\mathbf{C H}_{4} / \mathbf{C Y}_{\text {SOLIDS }}, \mathrm{g} / \mathrm{kg}\right)$ using the cheese yield $(\mathbf{C Y})$ obtained from model cheeses made from milk samples from every individual cow.

Following previous research, the objective of the present study was to compare 5 reference EME traits, estimated on the basis of $\mathrm{FA}_{\mathrm{GC}}$ and individual $\mathrm{CY}$, with the same EME traits predicted directly by IR spectrometry from milk spectra, or indirectly calculated on the basis of other IR-predicted traits $\left(\mathrm{FA}_{\mathrm{IR}}, \mathrm{CY}\right.$, dCMY). The EME traits studied were $\mathrm{CH}_{4}$ production $(\mathrm{g} / \mathrm{d})$, $\mathrm{CH}_{4}$ intensity $(\mathrm{g} / \mathrm{kg})$ per unit of milk, fresh cheese and cheese solids, and $\mathrm{CH}_{4}$ yield $(\mathrm{g} / \mathrm{kg})$ expressed per unit of DMI. 
MATERIALS AND METHODS

\section{Farms, Animals, and Samples}

We sampled 85 herds in Trento Province (northeastern Italian Alps) registered in the milk-recording program of the Provincial Breeders' Federation (FPA, Trento, Italy). The herds were selected from 610 farms to represent different environments and 4 dairy farming systems (Sturaro et al., 2013), ranging from very traditional (small farms, tied cows, hay-based diets) to intermediate (loose cattle, milking parlors, hay, and more concentrates), and modern (large farms using total mixed diets), with or without the use of silage. Details of the dairy systems and their effects on the reference EME traits are given in the previous study within the same project (Bittante et al., 2018).

Over a period of $1 \mathrm{yr}$, a total of 1,150 Brown Swiss cows from the 85 herds ( 15 cows per herd, with a few exceptions), at different parities and lactation stages, were sampled once (each herd on a different date) during the morning milking. Two milk subsamples per cow, representative of the whole milking, were taken and immediately refrigerated $\left(4^{\circ} \mathrm{C}\right)$ without preservative. One subsample $(50 \mathrm{~mL})$ was used to analyze milk quality traits, whereas the other $(2,000 \mathrm{~mL})$ was taken to the Cheese-Making Laboratory of the Department of Agronomy, Food, Natural Resources, Animals and Environment of the University of Padova (Legnaro, Padova, Italy) for individual model cheese making.

The milk was analyzed for fat and protein content according to the IR procedure approved by ICAR (2017) (see the section "Development of Direct and Indirect FTIR Calibration Models"). To correct the milk yield for milk fat and protein contents, in accordance with van Lingen et al. (2014), a correcting multiplicative factor $(\mathbf{C F})$ was calculated as follows $(\mathrm{CVB}, 2008)$ :

$$
\begin{aligned}
\mathrm{CF} & =0.337+0.116 \times \text { milk fat }(\%) \\
& +0.06 \times \text { milk protein }(\%) .
\end{aligned}
$$

The value $(\mathrm{kg} / \mathrm{d})$ of each cow's dCMY was calculated on the basis of its daily milk yield (dMY) on the day of sampling as follows:

$$
\operatorname{dCMY}(\mathrm{kg} / \mathrm{d})=\operatorname{dMY}(\mathrm{kg} / \mathrm{d}) \times \mathrm{CF} .
$$

\section{Individual Model Cheese Making}

The percentage fresh cheese yield $\left(\mathbf{\%} \mathbf{C} \mathbf{Y}_{\mathbf{C U R D}}\right)$ of individual cows was obtained through the model cheesemaking procedure described in detail by Cipolat-Gotet et al. (2013), and was expressed as

$$
\% \mathrm{CY}_{\mathrm{CURD}}=\frac{\text { weight of wheel, } \mathrm{g}}{\text { weight of milk, } \mathrm{g}} \times 100 \text {. }
$$

Similarly, the percentage cheese solids yield $\left(\mathbf{C} \mathbf{C Y}_{\text {Solids }}\right)$ was calculated as the ratio between the percentage DM multiplied by the weight of the fresh wheel (in the numerator) and the weight of the milk (in the denominator).

Each cow's daily production $(\mathrm{kg} / \mathrm{d})$ of fresh cheese $\left(\mathbf{d C Y} \mathbf{Y}_{\mathbf{C U R D}}\right)$ and cheese solids ( $\left.\mathbf{d} \mathbf{C} \mathbf{Y}_{\text {Solids }}\right)$ was calculated by multiplying the traits concerned $\left(\% \mathrm{CY}_{\text {CURD }}\right.$ or $\% \mathrm{CY}_{\text {SOLIDS }}$ ) by dMY:

$$
\begin{aligned}
\mathrm{dCY}_{\mathrm{CURD}} & =\mathrm{dMY} \times \% \mathrm{CY}_{\mathrm{CURD}} / 100 \\
\mathrm{dCY}_{\text {SOLIDS }} & =\mathrm{dMY} \times \% \mathrm{CY}_{\text {SOLIDS }} / 100
\end{aligned}
$$

\section{Milk FA Profiling}

Detailed FA profiles of the milk samples were obtained according to the method described in detail by Mele et al. (2016). Briefly, FAME were prepared by the direct extraction and alkali-catalyzed trans-methylation procedure, described by Feng et al. (2004). The FA composition was determined using a ThermoQuest gas chromatograph (Thermo Electron Corp., Waltham, MA) in split mode, fitted with a flame-ionization detector and a high polar fused-silica capillary column (Chrompack CP-Sil88, Varian, Middelburg, the Netherlands; $100 \mathrm{~m}, 0.25 \mathrm{~mm}$ i.d., film thickness 0.20 $\mu \mathrm{m})$. Inter- and intraassay coefficients of variation and correction factors for the short-chain FA (Mele et al., 2008) were also calculated using a reference standard butter (BCR 164, Commission of the European Communities, Community Bureau of Reference, Brussels, Belgium) with the analytical limit of detection set at $0.001 \%$ above that of the total amount of FA. Milk FA composition was expressed as grams per $100 \mathrm{~g}$ of total FA. In conformity with the equations of van Lingen et al. (2014), we examined the following FA: 4:0 (butyric acid); 16:0 iso (iso-palmitic acid); 18:1 trans-10 (iso-oleic acid); 18:1 trans-11 (vaccenic acid); 18:1 cis-9 (oleic acid); and 18:2 cis-9,cis-12 (linoleic acid).

\section{Definition of Reference Enteric Methane Emission Traits}

In the previous study (Bittante et al., 2018), we used 2 prediction equations for estimating $\mathrm{CH}_{4}$ yield $(\mathrm{g} / \mathrm{kg}$ of DMI) and $\mathrm{CH}_{4}$ intensity ( $\mathrm{g} / \mathrm{kg}$ of $\mathrm{CM}$ ) from milk $\mathrm{FA}_{\mathrm{GC}}$. These equations were developed by van Lingen et al. (2014) from a meta-analysis of 148 observations from 8 trials carried out with dairy cows on 30 differ- 
ent diets in respiration chambers in the Netherlands and the United Kingdom [coefficient of determination $\left(\mathbf{R}^{2}\right)=0.54$ and 0.47 , for $\mathrm{CH}_{4}$ yield and $\mathrm{CH}_{4}$ intensity, respectively]. From these 2 equations, and from measurements of daily milk yield and composition and of individual \% CY (fresh cheese and cheese solids), we derived the other EME traits as described in the aforementioned study (Bittante et al., 2018).

In accordance with the definitions of de Haas et al. (2017), we examined the following 5 traits as reference data for subsequent development of the IR predictions of EME traits:

- Methane yield: EME (g) per $\mathrm{kg}$ of DMI $\left(\mathbf{C H}_{4} /\right.$ DMI $_{\text {FAGC }}$ ) was predicted according to the equation of van Lingen et al. (2014):

$$
\begin{aligned}
& \mathrm{CH}_{4} / \mathrm{DMI}_{\mathrm{FAGC}}(\mathrm{g} / \mathrm{kg})=23.39+9.74 \\
& \times \mathrm{C} 16: 0 \text { iso }-1.06 \times \mathrm{C} 18: 1 \text { trans }-10 \\
& + \text { trans- } 11-1.75 \times \mathrm{C} 18: 2 \text { cis- } 9, \text { cis }-12
\end{aligned}
$$

where all FA are obtained from CG and expressed as $\%$ of the sum of all milk FA.

- Methane intensity-milk: EME (g) per kg of CM $\left(\mathbf{C H}_{4} / \mathbf{C M}_{\mathrm{FAGC}}\right)$ was predicted according to the equation of van Lingen et al. (2014):

$$
\begin{aligned}
\mathrm{CH}_{4} / \mathrm{CM}_{\mathrm{FAGC}}(\mathrm{g} / \mathrm{kg})=21.13-1.38 \times \mathrm{C} 4: 0 \\
+8.53 \times \mathrm{C} 16: 0 \text { iso }-0.22 \times \mathrm{C} 18: 1 \text { cis }-9-0.59 \\
\times \mathrm{C} 18: 1 \text { trans }-10+\text { trans }-11 .
\end{aligned}
$$

- Methane production: daily $\operatorname{EME~(g)~per~cow~}$ $\left(\mathrm{dCH}_{4}\right)$ was calculated as

$$
\mathrm{dCH}_{4}(\mathrm{~g} / \mathrm{d})=\mathrm{CH}_{4} / \mathrm{CM}_{\mathrm{FAGC}} \times \mathrm{dCMY} .
$$

- Methane intensity-cheese: EME (g) per $\mathrm{kg}$ of fresh cheese $\left(\mathrm{CH}_{4} / \mathrm{CY}_{\mathrm{CURD}}\right)$ was calculated as

$$
\mathrm{CH}_{4} / \mathrm{CY}_{\mathrm{CURD}}(\mathrm{g} / \mathrm{kg})=\mathrm{dCH}_{4} / \mathrm{dCY}_{\mathrm{CURD}} \text {. }
$$

- Methane intensity-cheese solids: EME (g) per kg of cheese solids $\left(\mathrm{CH}_{4} / \mathrm{CY}_{\text {SOLIDS }}\right)$ was calculated as

$$
\mathrm{CH}_{4} / \mathrm{CY}_{\text {SOLIDS }}(\mathrm{g} / \mathrm{kg})=\mathrm{dCH}_{4} / \mathrm{dCY}_{\text {SOLIDS }} \text {. }
$$

\section{Infrared Spectra Acquisition and Editing}

Within $20 \mathrm{~h}$ of milking, the full FTIR spectrum of absorbance of each sample was obtained from an FTIR spectrometer (MilkoScan FT 6000, Foss Electric,
Hillerød, Denmark). In total, 1,060 absorbance values were recorded for each milk sample covering the IR wavenumbers ranging from $5,000 / \mathrm{cm}$ (corresponding to a wavelength of $2.0 \mu \mathrm{m}$ ) in the near-IR subdivision of the IR area, through the mid-infrared (MIR) to wavenumber $930 / \mathrm{cm}$ (corresponding to a wavelength of 10.8 $\mu \mathrm{m})$ in the far infrared subdivision.

Prior to data analysis, each single wavenumber of the spectra was centered and standardized to a null mean and a unit sample variance (Ferragina et al., 2015). Mahalanobis distances were calculated by means of the Mahalanobis function in the $\mathrm{R}$ software (R Core Team, 2015, R Foundation for Statistical Computing, Vienna, Austria), the inverse of the spectral covariance matrix, and the "center" statement as a vector of 0 . Spectra with a distance greater than the mean \pm 3 standard deviations were classified as outliers (16 spectra). The spectra were not subjected to any other mathematical pretreatment. Preliminary analyses using the first and second derivatives of the absorbance values showed no relevant advantage in using these data rather than raw data without mathematical pretreatments $(-0.03$ to +0.06 of $\mathrm{R}^{2}$ ), which could be attributed to the Bayesian approach used for calibration.

\section{Calibration of EME Traits Using FTIR Spectra}

Separate models were fitted for all the EME traits and for the traits used for estimating them.

We used a Bayesian model, specifically the BayesB model, implemented in the BGLR package of the $\mathrm{R}$ software (de los Campos and Perez Rodriguez, 2015). Details of the procedure are described in Ferragina et al. (2015). Basically, phenotypes were regressed on standardized spectra covariates using the linear model:

$$
\mathrm{y}_{\mathrm{i}}=\beta_{0}+\sum_{\mathrm{j}=1}^{1,060} \mathrm{x}_{\mathrm{ij}} \beta_{\mathrm{j}}+\varepsilon_{\mathrm{i}},
$$

where $y_{i}$ is the measured phenotype of the ith sample, $\beta_{0}$ is an intercept, $\left\{\mathrm{x}_{\mathrm{ij}}\right\}$ are standardized FTIR wavelength data $(\mathrm{j}=1, \ldots, 1,060), \beta_{\mathrm{j}}$ is the effect of each wavelength, and $\varepsilon_{\mathrm{i}}$ are the model residuals assumed to be iid (independent and identically distributed) with normal distribution centered at zero with variance $\sigma_{\varepsilon}^{2}$. Given the above assumption, the conditional distribution of the data, given the effects and variance parameters, is

$$
P(\mathbf{y} \mid \boldsymbol{\theta})=\prod_{i=1}^{n} N\left(\mu_{i}, \sigma_{\varepsilon}^{2}\right)
$$


where $\mathbf{y}=\left\{y_{\mathrm{i}}\right\}, \boldsymbol{\theta}$ represents the collection of model parameters $\boldsymbol{\theta}=\left\{\beta_{0}, \boldsymbol{\beta}, \sigma_{\varepsilon}^{2}\right\}, N\left(\mu_{i}, \sigma_{\varepsilon}^{2}\right)$ is a normal distribution centered at $\mu_{i}($ mean $)=\beta_{0}+\sum_{\mathrm{j}=1}^{1,060} \mathrm{x}_{\mathrm{ij}} \beta_{\mathrm{j}}$ and with variance $\sigma_{\varepsilon}^{2}$, and $\boldsymbol{\beta}=\left\{\beta_{\mathrm{j}}\right\}$ is a vector containing the effects of the individual spectra-derived wavelengths. Specification of the Bayesian model is completed by assigning prior distribution to the unknowns, $\boldsymbol{\theta}$. The default values of the built-in BGLR rules were used for all the model's hyperparameters, and the inferences were based on 30,000 iterations and a burn-in of 10,000.

\section{Assessment of Prediction Accuracy Through Cross-Validation}

The accuracy of the prediction equations was assessed by a training-testing procedure. A training data set ( $80 \%$ of the total records) was used to build the equation, and a testing data set (20\% of the total) was used as validation. Samples were randomly assigned to the training or testing sets, and the training-testing procedure was repeated 10 times for each trait with different training and testing set samples each time. This procedure was used for all the traits studied. In each of the 10 training-testing trials of the prediction procedure for each trait, the observed and predicted values of the testing data set were used to calculate the coefficient of determination of cross-validation $\left(\mathrm{R}_{\mathrm{CV}}^{2}\right)$ and the root mean square error of cross-validation $\left(\mathrm{RMSE}_{\mathrm{CV}}\right)$. The coefficient of determination of calibration $\left(\mathrm{R}_{\mathrm{CAL}}^{2}\right)$ was also calculated using the measured and predicted values of each training data set. The final $\mathrm{R}_{\mathrm{CAL}}^{2}, \mathrm{R}_{\mathrm{CV}}^{2}$, and $\mathrm{RMSE}_{\mathrm{CV}}$ for each trait are averages of the 10 training-testing trials.

To identify the wavelengths relevant for predicting a given trait, the 1,060 equation coefficients corresponding to each wavelength for the considered trait were plotted together. The corresponding Pearson correlation values relative to the absorbance of each sample for every wavelength and the corresponding measured value of the trait of interest were also added to the figure. To facilitate description of the results throughout the spectral range, we divided the spectrum into 5 regions (Bittante and Cecchinato, 2013): the shortwave infrared (SWIR, often called near-infrared); the transition from near- to mid-infrared (SWIRMWIR), often referred to as the first "water" region; the first mid-infrared region (MWIR1); the second mid-infrared region (MWIR2), often referred to as the second "water" region, and the transition from mid- to long-infrared (MWIR-LWIR).

\section{Development of Direct and Indirect FTIR Calibration Models}

The above-described Bayesian approach was used for direct (direct-IR) prediction of the 5 EME traits. "Direct" refers to use of the 5 reference EME data (descriptive statistics are listed in Table 1) as dependent variables regressed against the 1,060 absorbance values of each FTIR spectrum. The direct-IR predicted EME traits were as follows:

- predicted $\mathrm{CH}_{4}$ yield $\left(\mathbf{C H}_{4} / \mathbf{D M I}_{\mathrm{IR}}, \mathrm{g} / \mathrm{kg}\right)$;

- predicted $\mathrm{CH}_{4}$ intensity-milk $\left(\mathbf{C H}_{4} / \mathbf{C M}_{\mathrm{IR}}, \mathrm{g} / \mathrm{kg}\right)$;

- predicted $\mathrm{CH}_{4}$ intensity-fresh cheese $\left(\mathbf{C H}_{4}\right)$ CY $_{\text {CURD-IR }}, \mathrm{g} / \mathrm{kg}$ );

- predicted $\mathrm{CH}_{4}$ intensity-cheese solids $\left(\mathbf{C H}_{4} /\right.$ $\mathbf{C Y}_{\text {SOLID-IR }}, \mathrm{g} / \mathrm{kg}$ ); and

- predicted daily $\mathrm{CH}_{4}$ production $\left(\mathbf{d C H}_{4-\mathrm{IR}}, \mathrm{g} / \mathrm{d}\right)$.

The same direct-IR model was also used to predict a further 15 informative traits (listed in Table 1) from the milk FTIR spectrum, which were previously used to calculate the reference EME traits (5 production traits, 4 cheese yield traits, and 6 milk FA proportions). The reference milk fat and protein contents shown in Table 1 were obtained using the same FTIR spectrometer and calibration equations pre-installed by the supplier company according to ICAR official methods (ICAR, 2017). Given that we used the same FTIR spectra, our fat and protein calibrations are then "calibrations of calibrations," and have the sole objective of testing the ability of our Bayesian approach to capture all the variability in the same spectra generated by the unknown calibration procedure used by the instrument supplier. The results are very satisfactory, with $R^{2}{ }_{\mathrm{CAL}}$ and $\mathrm{R}_{\mathrm{CV}}^{2}$ both greater than 0.99 (Table 1).

These direct-IR predictions of the informative traits were used to develop the following 8 indirect (indirectIR) procedures for predicting the same 5 EME traits:

- $\mathbf{C H}_{4} / \mathbf{D M I}_{\mathrm{FAIR}}$, using the same equations of van Lingen et al. (2014) for calculating the reference data, but with $\mathrm{FA}_{\mathrm{IR}}$ instead of $\mathrm{FA}_{\mathrm{GC}}$;

- $\mathbf{C H}_{4} / \mathbf{C M}_{\mathrm{FAIR}}$, again using equations of van Lingen et al. (2014), but with $\mathrm{FA}_{\mathrm{IR}}$ instead of $\mathrm{FA}_{\mathrm{GC}}$;

- $\mathbf{C H}_{4} / \mathbf{C Y}_{\text {CURD-IR-IR, using the same procedure as }}$ for the reference values, but substituting the reference $\mathrm{CH}_{4} / \mathrm{CM}_{\mathrm{FAGC}}$ with its IR prediction $\left(\mathrm{CH}_{4} /\right.$ $\mathrm{CM}_{\mathrm{IR}}$ ) and the measured $\% \mathrm{CY}_{\mathrm{CURD}}$ with its IR prediction;

- $\mathbf{C H}_{4} / \mathbf{C Y}_{\text {Solids-IR-IR, using the same procedure }}$ as for the reference values, but substituting the reference $\mathrm{CH}_{4} / \mathrm{CM}_{\mathrm{FAGC}}$ with its $\mathrm{IR}$ prediction 
$\left(\mathrm{CH}_{4} / \mathrm{CM}_{\mathrm{IR}}\right)$ and the measured $\% \mathrm{CY}_{\text {SOLIDS }}$ with its IR prediction;

- $\mathbf{d C H}_{4-\mathrm{CM}-\mathrm{IR}}$, by multiplying the measured corrected milk yield (dCMY) by the direct-IR $\mathrm{CH}_{4}$ intensity-milk $\left(\mathrm{CH}_{4} / \mathrm{CM}_{\mathrm{IR}}\right)$;

- $\mathbf{d C H}_{4-\mathrm{CM}-\mathrm{FAIR}}$, by multiplying the dCMY by the indirect-IR $\mathrm{CH}_{4}$ intensity-milk based on $\mathrm{FA}_{\mathrm{IR}}$ $\left(\mathrm{CH}_{4} / \mathrm{CM}_{\mathrm{FAIR}}\right)$;

- $\mathbf{d C H}_{4-I R-I R}$, by multiplying the IR predicted daily corrected milk yield $\left(\mathrm{dCM}_{\mathrm{IR}}\right)$ by the $\mathrm{CH}_{4} / \mathrm{CM}_{\mathrm{IR}}$;

- $\mathbf{d C H}_{\text {4-IR-FAIR }}$, by multiplying the $\mathrm{dCM}_{\mathrm{IR}}$ by the $\mathrm{CH}_{4} / \mathrm{CM}_{\mathrm{FAIR}}$.

\section{Analysis of the Sources of Variation in the Reference and Predicted EME Traits}

The parameters often used for evaluating IR predictions $\left(\mathrm{R}_{\mathrm{CV}}^{2}, \mathrm{RMSE}_{\mathrm{CV}}\right.$, and so on) are available only for direct-IR predictions of EME and other informative traits. To evaluate the indirect-IR EME predictions (but also the direct-IR EME predictions), we carried out another type of validation that involved analyzing their sources of variation and comparing them with those of the reference EME values. The objective was to assess whether the IR predictions are capable of capturing the relevant technological and biological information in the reference values. In particular, we analyzed the variability among the different herds and different animals, and in the effects of the dairy systems on the former, and of parity and lactation stage on the latter in both the reference and predicted traits. The fixed effects were assessed in terms of least squares means and the significance of the contrasts, and the random effects in terms of variances and their incidence on total variance. To do this, we adopted the same mixed linear model used in the previous study for analyzing the reference EME values (Bittante et al., 2018) to analyze the direct-IR and indirect-IR predictions:

$$
\begin{aligned}
& y_{i j k l m}=\mu+\text { dairy } \text { system }_{i}+\text { herd } / \text { date }_{j}(\text { dairy system })_{i} \\
& + \text { parity }_{k}+D I M_{l}+e_{i j k l m} \text {, }
\end{aligned}
$$

Table 1. Descriptive statistics and Fourier transform infrared milk spectra calibrations of enteric $\mathrm{CH}_{4}$ emissions

\begin{tabular}{|c|c|c|c|c|c|}
\hline Trait & Mean & $\mathrm{SD}$ & $\mathrm{R}_{\mathrm{CAL}}^{2}$ & $\mathrm{R}_{\mathrm{CV}}^{2}$ & $\mathrm{RMSE}_{\mathrm{CV}}$ \\
\hline \multicolumn{6}{|l|}{ Estimated $\mathrm{CH}_{4}$ emissions } \\
\hline $\mathrm{CH}_{4} / \mathrm{DMI}(\mathrm{g} / \mathrm{kg})$ & 21.3 & 1.6 & 0.64 & 0.49 & 1.18 \\
\hline $\mathrm{CH}_{4} / \mathrm{CM}(\mathrm{g} / \mathrm{kg})$ & 14.2 & 1.8 & 0.70 & 0.57 & 1.17 \\
\hline $\mathrm{dCH}_{4}(\mathrm{~g} / \mathrm{d})$ & 357 & 108 & 0.48 & 0.36 & 86.0 \\
\hline $\mathrm{CH}_{4} / \mathrm{CY}_{\mathrm{CURD}}(\mathrm{g} / \mathrm{kg})$ & 100 & 16 & 0.71 & 0.55 & 11.2 \\
\hline $\mathrm{CH}_{4} / \mathrm{CY}_{\text {SOLIDS }}(\mathrm{g} / \mathrm{kg})$ & 208 & 31 & 0.64 & 0.47 & 22.6 \\
\hline \multicolumn{6}{|l|}{ Milk production trait ${ }^{2}$} \\
\hline Milk yield $(\mathrm{kg} / \mathrm{d})$ & 24.5 & 7.9 & 0.57 & 0.44 & 5.9 \\
\hline Milk fat $(\%)$ & 4.22 & 0.69 & 0.999 & 0.994 & 0.07 \\
\hline Milk protein (\%) & 3.71 & 0.43 & 0.999 & 0.995 & 0.03 \\
\hline Correcting factor & 1.05 & 0.09 & 1.000 & 0.997 & 0.01 \\
\hline $\mathrm{dCMY}^{2}(\mathrm{~kg} / \mathrm{d})$ & 25.5 & 8.1 & 0.55 & 0.41 & 6.2 \\
\hline \multicolumn{6}{|l|}{ Cheese yield trait ${ }^{3}$} \\
\hline$\% \mathrm{CY}_{\mathrm{CURD}}(\%)$ & 15.05 & 1.90 & 0.81 & 0.72 & 1.02 \\
\hline$\% \mathrm{CY}_{\text {SOLIDS }}(\%)$ & 7.22 & 0.94 & 0.83 & 0.79 & 0.43 \\
\hline $\mathrm{dCY}_{\text {CURD }}(\mathrm{kg} / \mathrm{d})$ & 3.66 & 1.17 & 0.50 & 0.36 & 0.93 \\
\hline $\mathrm{dCY}_{\text {SOLIDS }}(\mathrm{kg} / \mathrm{d})$ & 1.76 & 0.57 & 0.55 & 0.41 & 0.43 \\
\hline \multicolumn{6}{|l|}{ Informative milk $\mathrm{FA}_{\mathrm{GC}}\left(\% \Sigma \mathrm{FA}_{\mathrm{GC}}\right)^{4}$} \\
\hline 4:0, butyric acid & 3.45 & 0.90 & 0.59 & 0.47 & 0.66 \\
\hline 16:0 iso, iso-palmitic acid & 0.32 & 0.09 & 0.40 & 0.30 & 0.08 \\
\hline $18: 1$ trans -10, iso-oleic acid & 0.29 & 0.09 & 0.56 & 0.42 & 0.07 \\
\hline $18: 1$ trans -11 , vaccenic acid & 1.20 & 0.37 & 0.60 & 0.43 & 0.28 \\
\hline 18:1 cis-9, oleic acid & 18.30 & 3.15 & 0.79 & 0.67 & 1.85 \\
\hline 18:2 cis-9, cis- 12 , linoleic acid & 2.05 & 0.60 & 0.64 & 0.49 & 0.44 \\
\hline
\end{tabular}
traits and of the traits used for their estimation $(\mathrm{N}=1,150 \text { cows from } 85 \text { herds })^{1}$

${ }^{1} \mathrm{R}_{\mathrm{CAL}}^{2}=$ coefficient of determination of calibration; $\mathrm{R}_{\mathrm{CV}}^{2}=$ coefficient of determination of cross-validation; $\mathrm{RMSE}_{\mathrm{CV}}=$ root mean square error of cross-validation; $\mathrm{CH}^{4} / \mathrm{DMI}=\mathrm{CH}_{4}$ yield per kilogram of DMI; $\mathrm{CH}_{4} / \mathrm{CM}$ $=\mathrm{CH}_{4}$ intensity of milk; $\mathrm{dCH}_{4}=$ daily $\mathrm{CH}_{4}$ production per cow; $\mathrm{CH}_{4} / \mathrm{CY}_{\mathrm{CURD}}\left(\mathrm{CH}_{4} / \mathrm{CY}_{\mathrm{SOLIDS}}\right)=\mathrm{CH}_{4}$ intensity of fresh cheese (or cheese solids).

${ }^{2} \mathrm{dCMY}=$ daily fat- and protein-corrected milk yield.

${ }^{3} \% \mathrm{CY}_{\mathrm{CURD}}=$ weight of fresh cheese as $\%$ of processed milk; $\% \mathrm{CY}_{\text {SOLIDS }}=$ weight of cheese solids as $\%$ of processed milk; $\mathrm{dCY}_{\mathrm{CURD}}=$ daily production of fresh cheese per cow; $\mathrm{dC} \mathrm{Y}_{\text {SOLIDS }}=$ daily production of cheese solids.

${ }^{4}$ Fatty acids ( $\% \Sigma \mathrm{FA}_{\mathrm{GC}}$, expressed as a percentage of gas total fatty acids in milk obtained by GC) included as independent variables in the equations used to estimate the enteric $\mathrm{CH}_{4}$ emissions (van Lingen et al., 2014). 
where $y_{i j k l m}$ is the observed trait; $\mu$ is the overall mean; dairy system ${ }_{i}$ is the fixed effect of the $i$ th dairy system $(i=1$ to 4$)$; herd/date ${ }_{j}(\text { dairy system })_{i}$ is the random effect of the $j$ th herd/date $(j=1$ to 85$)$ within the $i$ th dairy system; parity $_{k}$ is the fixed effect of the $k$ th parity ( $k=1$ to 5 for 1 to 5 or more lactations); $D I M_{l}$ is the $l$ th $60-\mathrm{d}$ class of DIM ( $l=1$ to 6 DIM classes); and $e_{i j k l m}$ is the residual random error term $\sim N\left(\mathbf{0}, \sigma_{e}^{2}\right)$. The significance of dairy system was tested on the error line of herd within dairy system, that of parity and DIM class on the error line of the residual variance.

Orthogonal post hoc contrasts were built to test the significance $(P<0.05)$ of dairy system and parity factors: (1) the "traditional" dairy system was compared with the "modern" systems; (2) within the modern systems, the "no TMR" herds were compared with the "TMR" herds; (3) within the TMR herds, those using silage were compared with those using water. First, second, third, and fourth parities were each compared with greater parities (e.g., 1st parity vs. 2nd-5th parities, 2 nd parity vs. 3 rd -5 th parities, and so on). In addition, linear, quadratic, and cubic contrasts were tested for the effect of DIM (Bittante et al., 2018).

\section{RESULTS}

\section{Descriptive Statistics and FTIR Calibrations}

Descriptive statistics and direct-IR calibration parameters of the EME traits and of the traits used to calculate them (milk production, cheese yield, and informative milk FA) are given in Table 1.

The reference (mean $\pm \mathrm{SD}) \mathrm{CH}_{4}$ yield $\left(\mathrm{CH}_{4} / \mathrm{DMI}\right)$ was $21.3 \pm 1.6 \mathrm{~g} / \mathrm{kg}$, and $\mathrm{CH}_{4}$ intensity-corrected milk $\left(\mathrm{CH}_{4} / \mathrm{CM}\right) 14.2 \pm 1.8 \mathrm{~g} / \mathrm{kg}$. We also predicted EME per cow per day $\left(\mathrm{dCH}_{4}, 357 \pm 108 \mathrm{~g} / \mathrm{d}\right), \mathrm{CH}_{4}$ intensityfresh cheese $\left(\mathrm{CH}_{4} / \mathrm{CY}_{\mathrm{CURD}}: 99.8 \pm 16.3 \mathrm{~g} / \mathrm{kg}\right)$, and $\mathrm{CH}_{4}$ intensity-cheese solids $\left(\mathrm{CH}_{4} / \mathrm{CY}_{\text {SOLIDS }}: 207.6 \pm 30.8 \mathrm{~g} /\right.$ $\mathrm{kg})$.

The $\mathrm{R}_{\mathrm{CAL}}^{2}$ and $\mathrm{R}_{\mathrm{CV}}^{2}$ of the direct-IR predictions of $\mathrm{CH}_{4} / \mathrm{DMI}$ were, respectively, 0.64 and 0.49 . Those of $\mathrm{CH}_{4} / \mathrm{CM}$ were slightly more accurate $(0.70$ and 0.57$)$, similar to those of $\mathrm{CH}_{4} / \mathrm{CY}_{\mathrm{CURD}}(0.71$ and 0.55$)$ and slightly better than those of $\mathrm{CH}_{4} / \mathrm{CY}_{\text {SOLIDS }}$ (0.64 and $0.47)$. These calibration and cross-validation parameters are in the range of those obtained for the direct-IR predictions of the informative FA used for calculating the reference values $\left(\mathrm{R}_{\mathrm{CAL}}^{2}: 0.40\right.$ to $0.79 ; \mathrm{R}_{\mathrm{CV}}^{2}: 0.30$ to 0.67; Table 1).

Direct-IR prediction of $\mathrm{dCH}_{4}$ was less accurate $\left(\mathrm{R}_{\mathrm{CAL}}^{2}\right.$ $\left.0.48, R_{\text {VAL }}^{2} 0.36\right)$ than direct-IR prediction of the other EME traits. These calibration and cross-validation parameters are only slightly lower than those obtained for the other "daily quantity" traits (dMY, dCMY, $\mathrm{dC} \mathrm{Y}_{\mathrm{CURD}}$, and $\left.\mathrm{dC} \mathrm{Y}_{\text {SOLIDS }}\right)$.

The coefficients of each wavenumber for every directIR predicted EME trait are plotted in Figures 1 and 2 , together with the Pearson correlations between each absorbance and EME trait. To facilitate interpretation of the results, the 5 most informative wavenumbers of each prediction equation of the EME traits (those with the highest coefficients in absolute value) are given in Table 2, which also shows the major wavenumbers of the other informative traits in the same area of the spectrum obtained in this or in previous studies. We can see that the near-IR (SWIR) region of the FTIR spectrum $(5,000$ to 3,673 waves $/ \mathrm{cm})$ is not important for predicting EME traits, as only one of the $25 \mathrm{im}-$ portant signals included in Table 2 was found there $(3,978 / \mathrm{cm})$ and was related to predicting $\mathrm{CH}_{4} / \mathrm{CM}$. No important signals were observed in either of the 2 "water absorption" regions of the FTIR spectrum (SWIR-MWIR 3,669 to 3,052, and MWIR2 1,698 to 1,586 waves $/ \mathrm{cm}$ ). The large majority of important signals are concentrated in the central part of the MIR (MWIR1) section $(3,048$ to $1,701 / \mathrm{cm})$, where we found 3 signals of $\mathrm{dCH}_{4}, 3$ of $\mathrm{CH}_{4} / \mathrm{DMI}$, and 8 of $\mathrm{CH}_{4}$ intensities, and in the transition area from MIR to far infrared wavenumbers (MWIR/LWIR, 1,582 to $930 / \mathrm{cm}$ ), where we found 2 signals of $\mathrm{dCH}_{4}, 2$ of $\mathrm{CH}_{4} / \mathrm{DMI}$, and 6 of $\mathrm{CH}_{4}$ intensities.

\section{Sources of Variation in the Reference and in the Directly or Indirectly IR-Predicted EME Traits}

Table 3 summarizes the results of the regressions of the predicted (direct-IR and indirect-IR) $\mathrm{CH}_{4}$ yield and $\mathrm{CH}_{4}$ intensity-milk traits on the corresponding reference traits, and also shows the results of the statistical analyses (effects of dairy system, herd within dairy system, parity, and DIM) of the reference and predicted (direct-IR and indirect-IR) EME traits.

The linear regressions of the direct-IR predicted EME traits on the corresponding reference traits (derived from $\mathrm{FA}_{\mathrm{GC}}$ ) yielded intercepts that did not differ significantly from the expected 0.00 , slopes that did not differ from the expected 1.00, and correlation coefficients of 0.76 for $\mathrm{CH}_{4} / \mathrm{DMI}_{\mathrm{IR}}$ and 0.83 for $\mathrm{CH}_{4} / \mathrm{CM}_{\mathrm{IR}}$. The ANOVA of the 2 direct-IR predictions was substantially equivalent to that of the corresponding reference data, both having very similar levels of significance and least squares means for all the factors included in the model, as well as similar incidences of herd variance on total variance. The only appreciable difference is that both direct-IR-predicted EME traits have a lower 
RMSE than the corresponding reference data, probably because milk spectra have greater repeatability. The 2 indirect-IR predictions $\left(\mathrm{CH}_{4} / \mathrm{DMI}_{\mathrm{FAIR}}\right.$ and $\mathrm{CH}_{4} /$ $\mathrm{CM}_{\mathrm{FAIR}}$ ) based on IR predictions of informative FA and the equations of van Lingen et al. (2014) were also substantially equivalent to the direct-IR predictions in terms of the regression on the reference data and sources of variation.

Table 4 displays the same information as Table 3 (reference data, direct-IR, and indirect-IR predictions), but for $\mathrm{CH}_{4} / \mathrm{CY}_{\mathrm{CURD}}$ and $\mathrm{CH}_{4} / \mathrm{CY}_{\text {SOLIDS }}$. Here, too, the intercepts and slopes of the linear regressions of the direct-IR predictions did not differ from theoretical expectations, and the correlation coefficients were equivalent to or lower than those for $\mathrm{CH}_{4} / \mathrm{CM}_{\mathrm{IR}}$. The least squares means and the levels of significance of the sources of variation obtained by an ANOVA of both direct-IR predictions differed slightly from those obtained from the reference data. The lower residual variability of the direct-IR predictions was not, in this
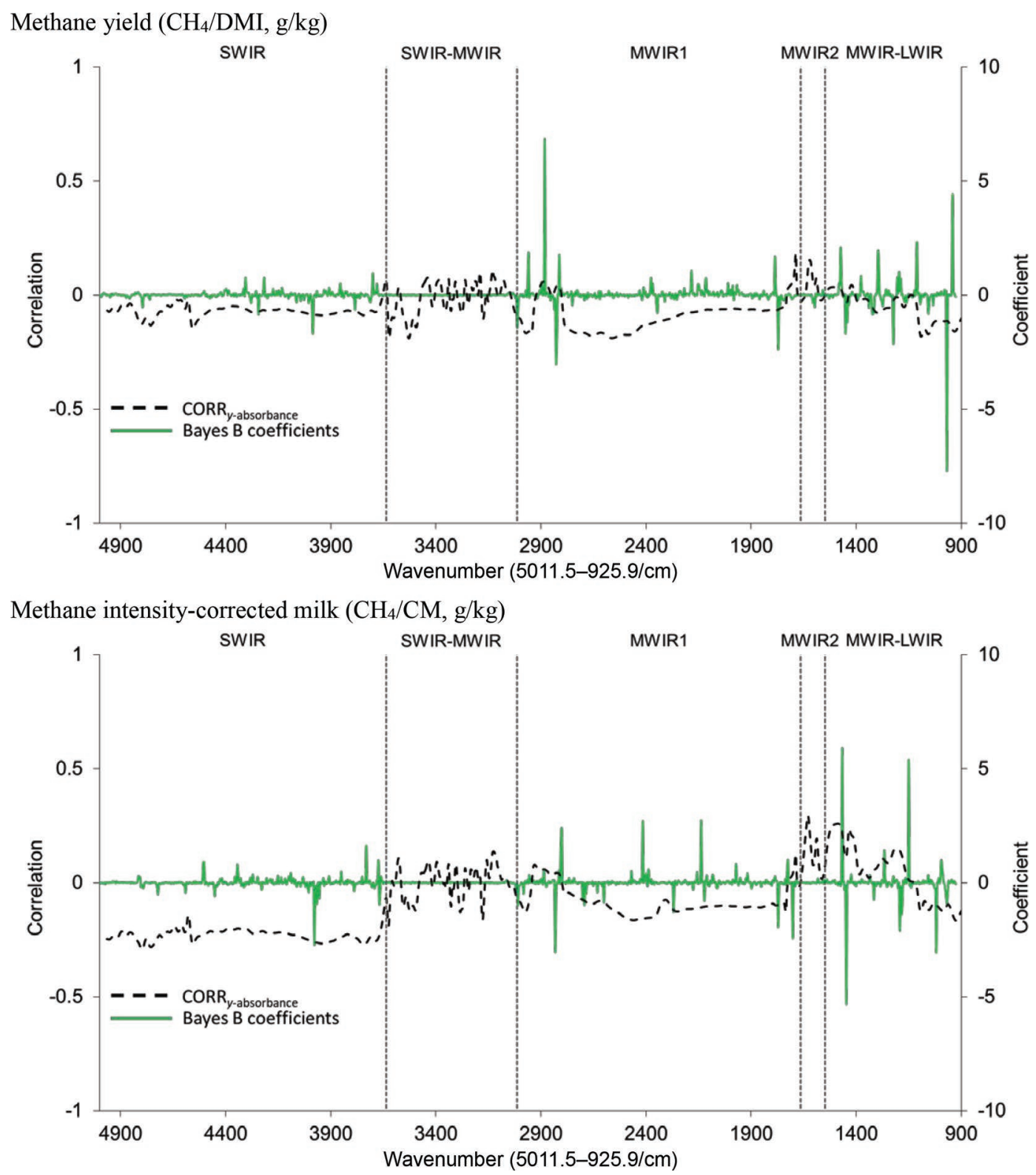

Figure 1. Direct-infrared prediction equation coefficients obtained using the variable selection Bayesian (BayesB) method (solid line) and simple correlation (CORR) coefficients (dashed line) for the absorbance of each wavenumber of the milk Fourier transform infrared spectrum for the prediction of $\mathrm{CH}_{4}$ yield $\left(\mathrm{CH}_{4} / \mathrm{DMI}, \mathrm{g} / \mathrm{kg}\right)$ and $\mathrm{CH}_{4}$ intensity-corrected milk $\left(\mathrm{CH}_{4} / \mathrm{CM}, \mathrm{g} / \mathrm{kg}\right)$. SWIR = short-wave infrared (i.e., nearinfrared); MWIR = mid-wave infrared (i.e., mid-infrared), where MWIR1 is the first mid-infrared region and MWIR2 is the second mid-infrared region; and LWIR = long-wave infrared (i.e., far-infrared). Color version available online. 
Methane production $\left(\mathrm{dCH}_{4}, \mathrm{~g} / \mathrm{d}\right)$

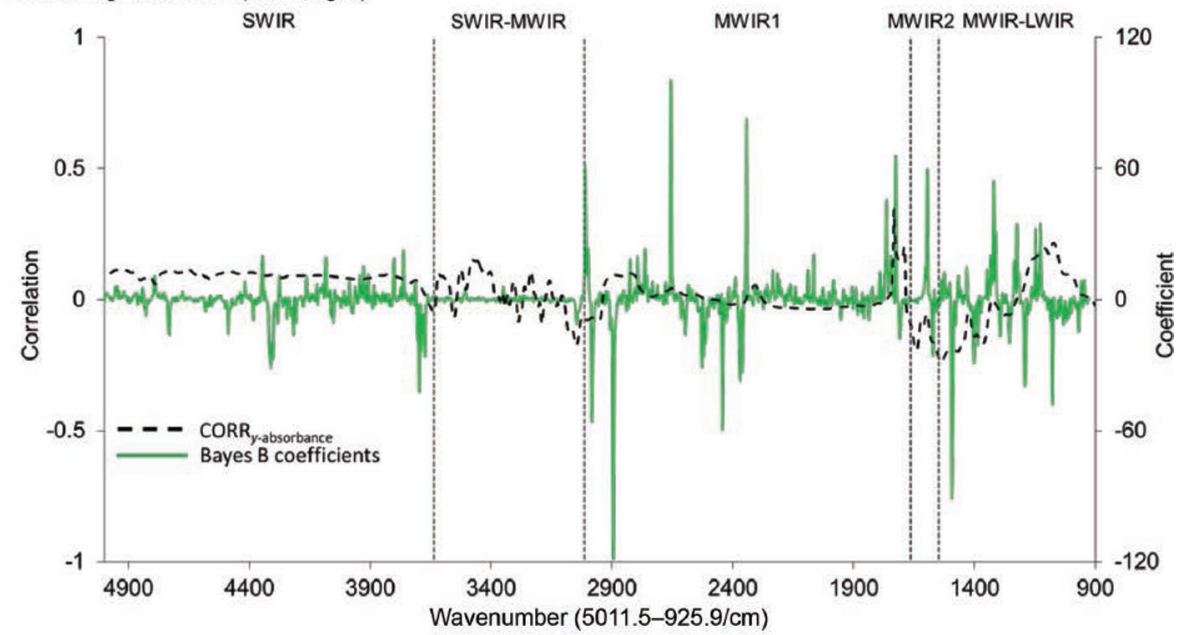

Methane intensity-fresh cheese $\left(\mathrm{CH}_{4} / \mathrm{CY}_{\mathrm{CURD}}, \mathrm{g} / \mathrm{kg}\right)$

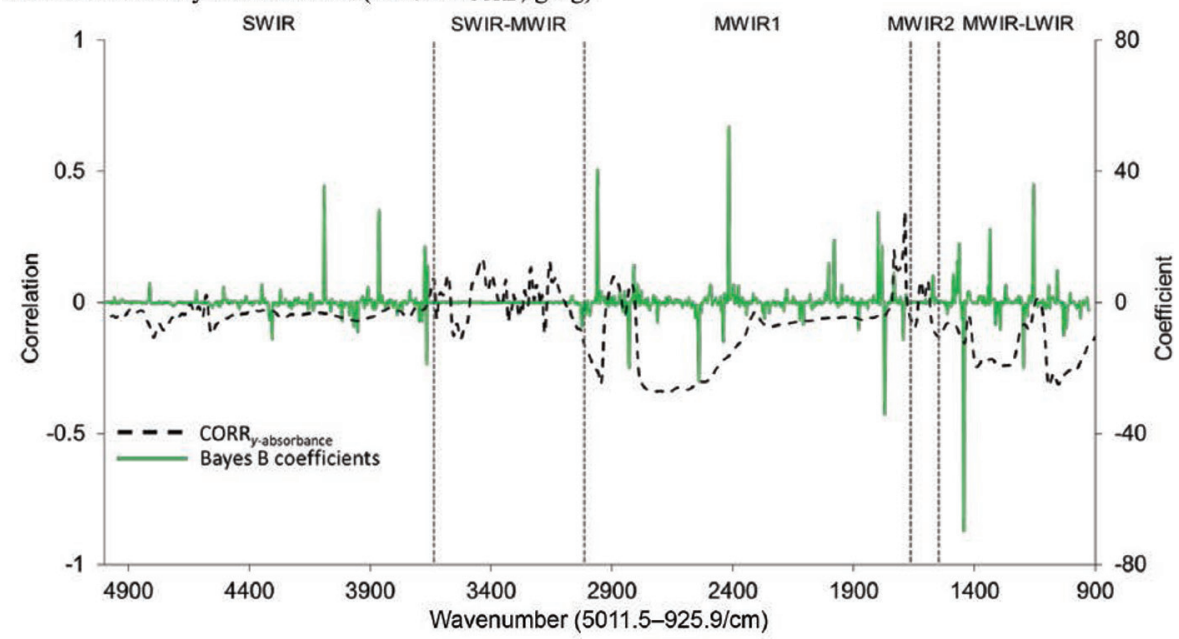

Methane intensity-cheese solids $\left(\mathrm{CH}_{4} / \mathrm{CY}_{\text {SOLIDS, }} \mathrm{g} / \mathrm{kg}\right)$

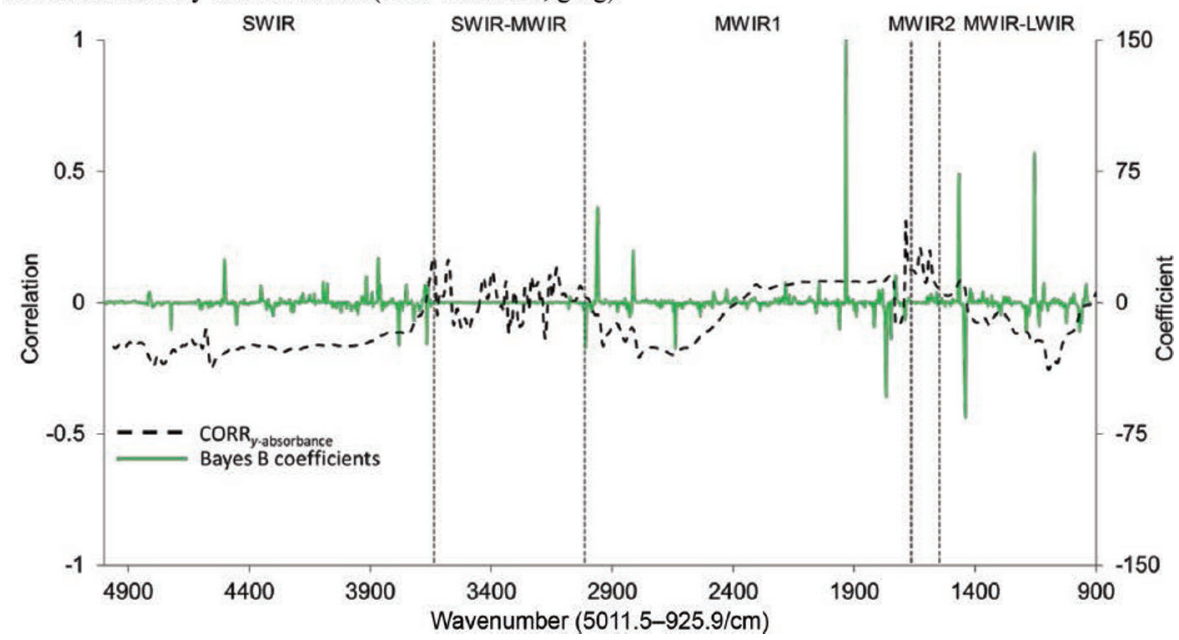

Figure 2. Direct-infrared prediction equation coefficients obtained using the variable selection Bayesian (BayesB) method (solid line) and simple correlation (CORR) coefficients (dashed line) for the absorbance of each wavenumber of the milk Fourier transform infrared spectrum for the prediction of daily $\mathrm{CH}_{4}$ production per cow $\left(\mathrm{dCH}_{4}, \mathrm{~g} / \mathrm{d}\right)$ and of $\mathrm{CH}_{4}$ intensity per unit of fresh cheese $\left(\mathrm{CH}_{4} / \mathrm{CY}_{\mathrm{CURD}}, \mathrm{g} / \mathrm{kg}\right)$ and cheese solids $\left(\mathrm{CH}_{4} / \mathrm{CY}_{\text {SOLIDS }}, \mathrm{g} / \mathrm{kg}\right)$. SWIR = short-wave infrared (i.e., near-infrared), where MWIR1 is the first mid-infrared region and MWIR2 is the second mid-infrared region; MWIR = mid-wave infrared (i.e., mid-infrared); and LWIR = long-wave infrared (i.e., far-infrared). Color version available online. 
case, accompanied by a parallel decrease in herd variability, so that the incidence of this variance on total variance was greater.

Unlike $\mathrm{CH}_{4}$ yield and $\mathrm{CH}_{4}$ intensity-milk, shown in Table 3, the indirect-IR predictions of $\mathrm{CH}_{4}$ intensityfresh cheese $\left(\mathrm{CH}_{4} / \mathrm{CY}_{\text {CURD-IR-IR }}\right)$ and $\mathrm{CH}_{4}$ intensitycheese solids $\left(\mathrm{CH}_{4} / \mathrm{CY}_{\text {SOLIDS-IR-IR }}\right)$ were not based on $\mathrm{FA}_{\mathrm{IR}}$, but on the IR predictions of $\mathrm{CH}_{4}$ production $\left(\mathrm{dCH}_{4-\mathrm{IR}}\right)$ divided by the IR predictions of daily cheese production ( $\mathrm{dCY}_{\mathrm{CURD}-\mathrm{IR}}$ and $\left.\mathrm{dCY}_{\text {SOLIDS-IR }}\right)$. The results in both cases are much less satisfactory than the results of the direct-IR predictions of the 2 EME traits. In fact, the intercepts and slopes of the linear regressions on the reference data differed significantly from the expected 0.00 and 1.00, respectively, and the correlation coefficients were lower $(0.67$ and 0.62 vs. 0.81 and 0.78 , respectively). Moreover, the least squares means estimations and levels of significance obtained by an ANOVA of these 2 indirect-IR predictions differed from the reference and direct-IR predicted EME traits. Lastly, the residual variability was in both these cases higher than the reference and the direct-IR predicted traits, but herd variability was not, so its incidence on total variance was lower.

In the case of $\mathrm{dCH}_{4}(\mathrm{~g} / \mathrm{d})$ per cow, aside from the reference trait, there are 5 alternative IR predictions (Table 5): the direct-IR and the 4 indirect-IR predicted traits. Two of the latter were obtained by multiplying the measured dCMY $(\mathrm{kg} / \mathrm{d})$ by the $\mathrm{CH}_{4} / \mathrm{CM}_{\mathrm{IR}}$ or by the $\mathrm{CH}_{4} / \mathrm{CM}_{\mathrm{FAIR}}$ predicted $\mathrm{CH}_{4}$ intensity, whereas the other 2 were obtained in the same way, but using the IR predicted $\mathrm{dCM}\left(\mathrm{dCM}_{\mathrm{IR}}, \mathrm{kg} / \mathrm{d}\right)$ instead of the measured value.

The intercept and slope of the regression of the direct-IR predicted $\mathrm{dCH}_{4-\mathrm{IR}}$ with the reference values did not differ from expectations, although the correlation coefficient was not very high (0.68). The ANOVA of direct-IR $\mathrm{CH}_{4}$ production resulted in lower residual

Table 2. Most important electromagnetic waves for predicting enteric $\mathrm{CH}_{4}$ emissions (EME) and other milk traits ${ }^{1}$

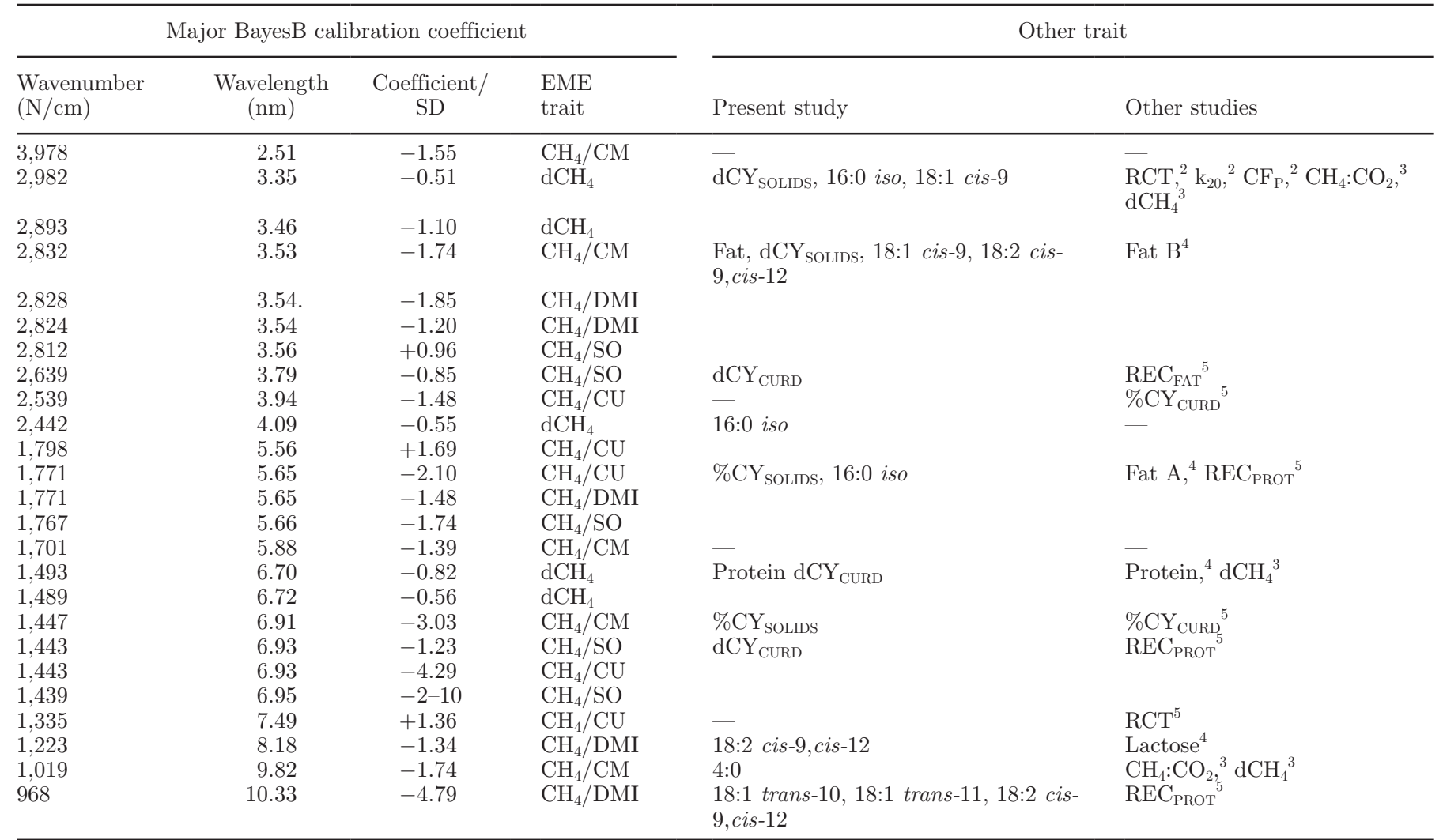

${ }^{1}$ BayesB $=$ Bayesian selection method; $\mathrm{dCY} \mathrm{Y}_{\mathrm{SOLIDS}}=$ daily production of cheese solids; $\mathrm{dCY} \mathrm{Y}_{\mathrm{CURD}}=$ daily production of fresh cheese per cow; $\% \mathrm{CY}_{\mathrm{CURD}}=$ percentage fresh cheese yield $; \mathrm{CY}_{\text {SOLIDS }}=$ percentage cheese solids yield; $\mathrm{dCH}_{4}=$ daily $\mathrm{CH}_{4}$ production per cow; $\mathrm{CM}=$ corrected milk; $\mathrm{SO}=\% \mathrm{CY}_{\mathrm{SOLIDS}} ; \mathrm{CU}=\% \mathrm{CY}_{\mathrm{CURD}} ; \mathrm{RCT}=$ rennet coagulation time, $\mathrm{k}_{20}=$ curd firming time, $\mathrm{CF}_{\mathrm{P}}=$ potential curd firmness, $\mathrm{REC}_{\mathrm{FAT}}=$ recovery of milk fat in cheese, $\mathrm{REC}_{\mathrm{PROT}}=$ recovery of milk protein in cheese.

${ }^{2}$ BayesB coefficients according to Ferragina et al. (2017).

${ }^{3}$ Recursive partial least squares variable importance in projection scores according to Shetty et al. (2017).

${ }^{4}$ Wavenumber of filters used in monochromatic infrared according to Lynch et al. (2006) and Kaylegian et al. (2009).

${ }^{5}$ BayesB coefficients according to Ferragina et al. (2015). 
Table 3. Linear regression and ANOVA for $\mathrm{CH}_{4}$ yield $\left(\mathrm{CH}_{4} / \mathrm{DMI}, \mathrm{g} / \mathrm{kg}\right)$ and $\mathrm{CH}_{4}$ intensity $\left(\mathrm{CH}_{4} / \mathrm{CM}\right.$, g/kg) estimated on the basis of milk fatty acids analyzed by GC (reference, FAGC), directly predicted by milk infrared spectra (direct-IR), or indirectly estimated on the basis of fatty acids predicted by infrared (indirect IR, FAIR)

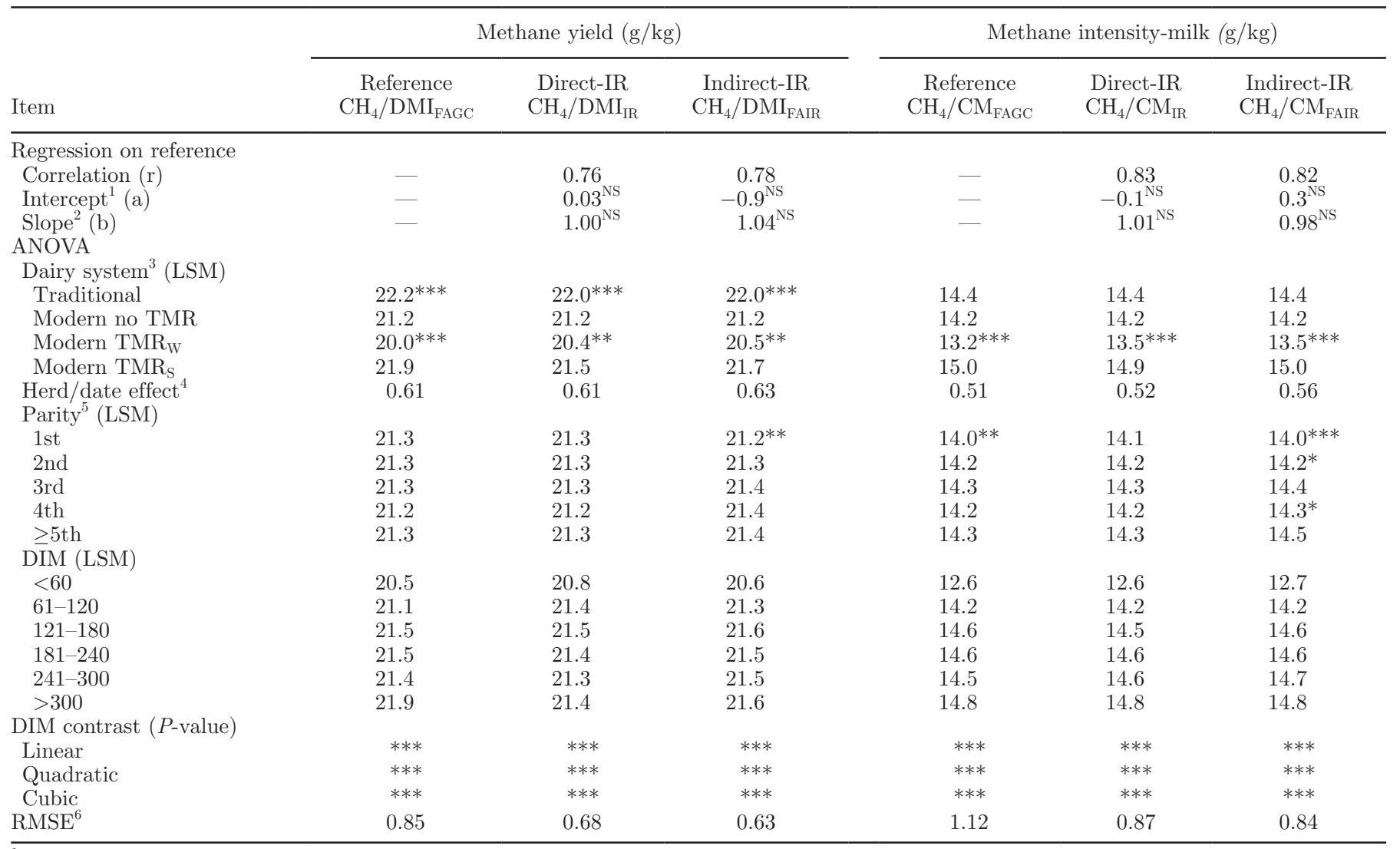

${ }^{1}$ Significance (NS and asterisks) refers to the difference between intercept estimate and the expected 0.00 value.

${ }^{2}$ Significance (NS and asterisks) refers to the difference between slope estimate and the expected 1.00 value.

${ }^{3}$ Asterisks refers to the significance of the orthogonal contrasts between the traditional dairy system versus all the modern ones (in the line "Traditional"); among modern dairy systems, the farms not using total mixed diets versus those using it (in the line "Modern no TMR"); among farms using TMR between those adding water $\left(\mathrm{TMR}_{\mathrm{W}}\right)$ versus those adding silages $\left(\mathrm{TMR}_{\mathrm{S}}\right)$ to moisturize the diet (in the line "Modern TMR $\mathrm{W}_{\mathrm{W}}$ ).

${ }^{4}$ The variance of herd/date within dairy system, expressed as ratio with total variance.

${ }^{5}$ Asterisks refer to the orthogonal contrast between primiparous and multiparous (in the line "1st"); between second calvers and third and more calvers (in the line "2nd"); between third calvers and fourth and more calvers (in the line "3rd"); between fourth calvers and cows with 5 or more calvings (in the line "4th").

${ }^{6} \mathrm{RMSE}=$ root mean square error.

${ }^{*} P<0.05 ;{ }^{* *} P<0.01 ;{ }^{* * *} P<0.001$.

and herd variances, some differences in the significance levels of the effects of parity and DIM, and in general, the least squares means of the various fixed factors (dairy system, parity, and DIM class) there being fewer differences among them than among the corresponding reference values.

The indirect-IR predictions of $\mathrm{dCH}_{4}$ obtained by multiplying measured $\mathrm{dCM}$ by $\mathrm{CH}_{4} / \mathrm{CM}_{\mathrm{IR}}$ or by $\mathrm{CH}_{4} /$ $\mathrm{CM}_{\mathrm{FAIR}}$ were much closer to the reference values than the direct-IR predictions, and had a very high correlation (0.96) and yielded very similar information to the ANOVA. When we used IR-predicted milk yield $\left(\mathrm{dCMY}_{\mathrm{IR}}\right)$ instead of the measured dCMY to indirectly predict $\mathrm{CH}_{4}$ production, the linear regressions with the reference data and the ANOVA of the predictions were very similar to or even less satisfactory than the directIR predictions.

\section{DISCUSSION}

The estimated EME traits obtained with the reference method based on the FA profiles of milk analyzed by GC, together with the other traits (milk production, cheese-yields) used for the calculations, were reported and discussed in a previous study within the same project (Bittante et al., 2018) and will not be discussed here. Nor will we discuss the detailed FA profiles of all the cows in this study, as they were previously analyzed 
Table 4. Linear regression and ANOVA of $\mathrm{CH}_{4}$ intensity-fresh cheese $\left(\mathrm{CH}_{4} / \mathrm{CY}_{\mathrm{CURD}}, \mathrm{g} / \mathrm{kg}\right)$ and -cheese solids $\left(\mathrm{CH}_{4} / \mathrm{CY}_{\mathrm{SOLIDS}}, \mathrm{g} / \mathrm{kg}\right)$ estimated on the basis of reference $\mathrm{CH}_{4} / \mathrm{CM}$ divided by measured cheese yield (reference, $\mathrm{CH}_{4} / \mathrm{CM} / \mathrm{CY}$ ), directly predicted by milk infrared spectra (direct-IR), or indirectly estimated dividing $\mathrm{CH}_{4} / \mathrm{CM}$ by $\mathrm{CY}$, both predicted by infrared (indirect-IR)

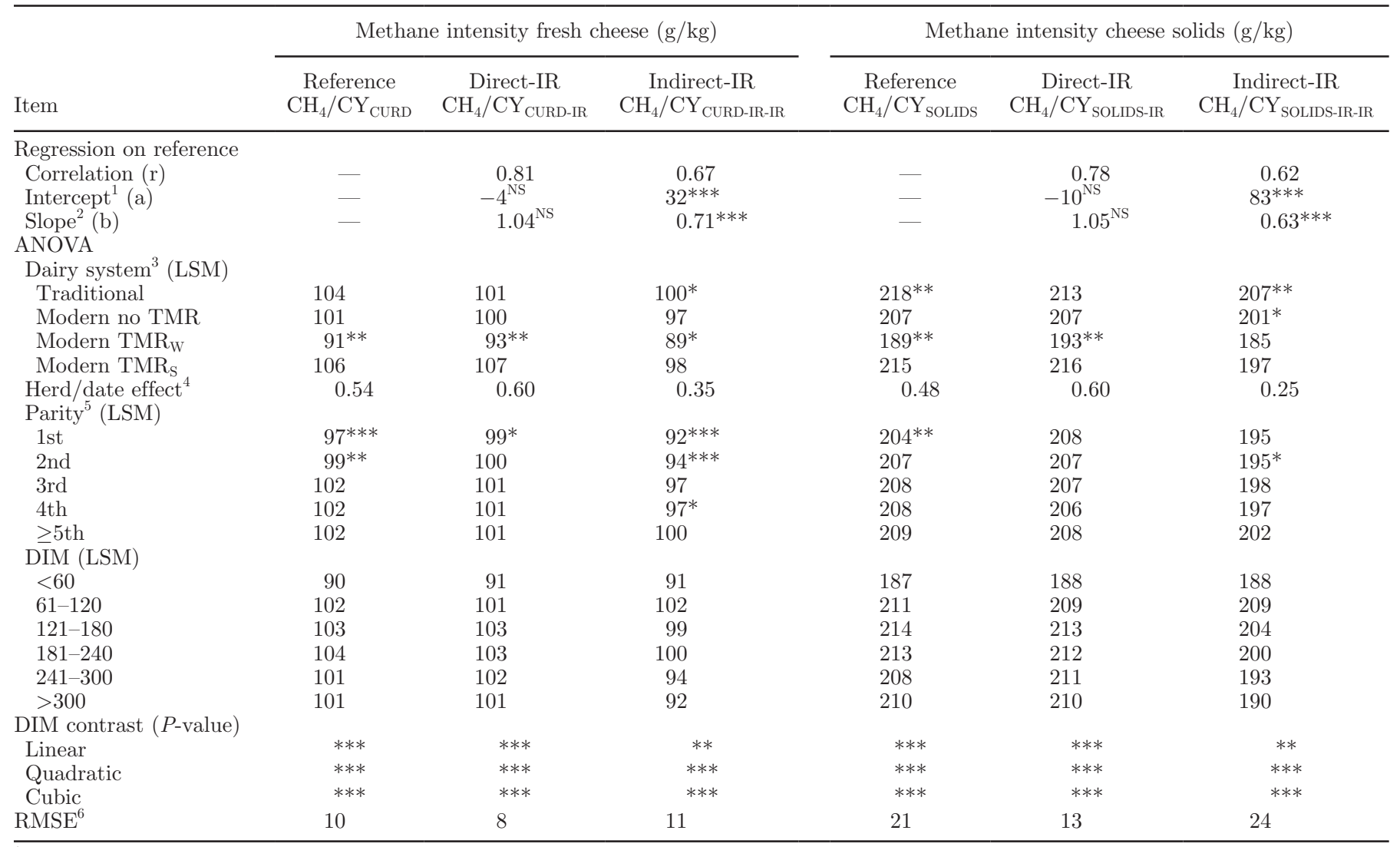

${ }^{1}$ Significance (NS and asterisks) refers to the difference between intercept estimate and the expected 0.00 value.

${ }^{2}$ Significance (NS and asterisks) refers to the difference between slope estimate and the expected 1.00 value.

${ }^{3}$ Asterisks refer to the significance of the orthogonal contrasts between the traditional dairy system versus all the modern ones (in the line "Traditional"); among modern dairy systems, the farms not using total mixed diets versus those using it (in the line "Modern no TMR"); among farms using TMR between those adding water $\left(\mathrm{TMR}_{W}\right)$ versus those adding silages $\left(\mathrm{TMR}_{\mathrm{S}}\right)$ to moisturize the diet (in the line "Modern $\mathrm{TMR}$ ").

${ }^{4}$ The variance of herd/date within dairy system, expressed as a ratio with total variance.

${ }^{5}$ Asterisks refer to the orthogonal contrast between primiparous and multiparous (in the line "1st"); between second calvers and third and more calvers (in the line "2nd"); between third calvers and fourth and more calvers (in the line "3rd"); between fourth calvers and cows with 5 or more calvings (in the line " 4 th").

${ }^{6} \mathrm{RMSE}=$ root mean square error.

${ }^{*} P<0.05 ;{ }^{* *} P<0.01 ;{ }^{* * *} P<0.001$.

with the aim of identifying their latent explanatory factors (Mele et al., 2016), and their heritability and genetic, herd and residual correlations and clustering (Pegolo et al., 2016), and were subjected to genomewide association and network analysis (Pegolo et al., 2017).

The equations for estimating the EME traits based on $\mathrm{FA}_{\mathrm{GC}}$ were developed by van Lingen et al. (2014) by regressing the $\mathrm{FA}_{\mathrm{GC}}$ profiles of milk against the emissions obtained with the gold standard method in respiration chambers, using data obtained from a meta-analysis of 8 trials comprising 148 observations of cows on 30 different diets in 2 countries (the United Kingdom and the Netherlands). The coefficient of determination of the 2 equations used ( 0.54 for $\mathrm{CH}_{4}$ yield, 0.47 for $\mathrm{CH}_{4}$ intensity-milk) were, as often happens with meta-analyses, lower than those drawn from single-experiment studies (van Gastelen and Dijkstra, 2016), but produced results that were appreciably accurate and precise. We preferred to use these equations because they were based on a large data set representing a wide variety of feeding and management conditions, and the cows' average milk production was very similar to that in our study. The results using these equations differed little to those obtained with other direct methods that did not use respiration chambers but were instead based on sampling the air near the cows' nostrils in an open environment (Negussie et al., 2017). It should, however, 
be noted that the value of these estimates depends on the characteristics of the method used (with or without a tracer gas in the rumen, frequency and distribution during the $24 \mathrm{~h}$ of air sampling, type of instrument, and so on) and they have recently been questioned (Hristov et al., 2016; Wu et al., 2018).

The major difference between our survey at field level and van Lingen et al. (2014) is the breed of the cows (Brown Swiss vs. Holstein Friesian). However, we should point out that breed is a minor source of variation in the FA profiles (FA expressed as proportions of their sum) of milk produced by cows in the same type of environment, with the exception of Jersey cows, because their milk has a greater fat content and fat globule size (Kelsey et al., 2003; Soyeurt et al., 2006; MauriceVan Eijndhoven et al., 2013). Almost no information is available on the effect of breed on EME traits, although there is reason to assume that the cow's breed has an almost null effect on its rumen microbiota activity when feed regimen and milk production are comparable. Xue et al. (2011) compared Jersey crossbreds with Holsteins purebreds and found many productive and metabolic differences between the 2 genotypes, but the energy loss from EME as a ratio of total energy intake was very

Table 5. Linear regression and ANOVA of daily $\mathrm{CH}_{4}$ production $\left(\mathrm{dCH}_{4}, \mathrm{~g} / \mathrm{d}\right)$ calculated multiplying the measured daily corrected milk yield (dCM) by the $\mathrm{CH}_{4}$ intensity-milk (reference), directly predicted by milk infrared spectra (direct-IR), or indirectly calculated multiplying the measured dCM or the infrared predicted $\mathrm{dCM}$ by the $\mathrm{CH}_{4}$ intensity directly predicted by infrared or indirectly estimated by IR-predicted fatty acids (FAIR)

\begin{tabular}{|c|c|c|c|c|c|c|}
\hline \multirow[b]{2}{*}{ Item } & \multicolumn{6}{|c|}{ Methane production $(\mathrm{g} / \mathrm{d})$} \\
\hline & $\begin{array}{l}\text { Reference } \\
\mathrm{dCH}_{4}\end{array}$ & $\begin{array}{c}\text { Direct-IR } \\
\mathrm{dCH}_{4-\mathrm{IR}}\end{array}$ & $\mathrm{dCH}_{4-\mathrm{CM}-\mathrm{IR}}$ & $\mathrm{dCH}_{4 \text {-CM-FAIR }}$ & $\mathrm{dCH}_{4-\mathrm{IR}-\mathrm{IR}}$ & $\mathrm{dCH}_{4-\mathrm{IR} \text {-FAIR }}$ \\
\hline \multicolumn{7}{|c|}{ Regression on reference } \\
\hline Correlation $(\mathrm{r})$ & - & 0.68 & 0.96 & 0.96 & 0.65 & 0.63 \\
\hline Intercept $^{1}$ (a) & - & $16^{\mathrm{NS}}$ & $4^{\mathrm{NS}}$ & $8^{* *}$ & $68^{* * *}$ & $84^{* * *}$ \\
\hline \multicolumn{7}{|c|}{ Dairy system ${ }^{3}$ (LSM) } \\
\hline Traditional & $307^{* * *}$ & $335^{* * *}$ & $305^{* * *}$ & $308^{* * *}$ & $332^{* * *}$ & $335^{* * *}$ \\
\hline Modern no TMR & $368^{* *}$ & $357^{* *}$ & $367^{* *}$ & $368^{* * *}$ & $351^{* * *}$ & $351^{* * *}$ \\
\hline Modern $\mathrm{TMR}_{\mathrm{W}}$ & $390^{*}$ & $377^{*}$ & 399 & $398^{*}$ & $376^{*}$ & $375^{* *}$ \\
\hline Modern $\mathrm{TMR}_{\mathrm{S}}$ & 444 & 416 & 441 & 444 & 421 & 425 \\
\hline Herd/date effect ${ }^{4}$ & 0.34 & 0.27 & 0.36 & 0.34 & 0.30 & 0.28 \\
\hline \multicolumn{7}{|l|}{ Parity $^{5}$ (LSM) } \\
\hline \multicolumn{7}{|l|}{ DIM (LSM) } \\
\hline$<60$ & 399 & 402 & 402 & 405 & 407 & 411 \\
\hline $61-120$ & 422 & 400 & 423 & 423 & 396 & 398 \\
\hline $121-180$ & 402 & 381 & 403 & 403 & 379 & 379 \\
\hline $181-240$ & 377 & 366 & 377 & 377 & 364 & 365 \\
\hline $241-300$ & 338 & 349 & 342 & 342 & 347 & 348 \\
\hline$>300$ & 325 & 330 & 327 & 327 & 326 & 328 \\
\hline \multicolumn{7}{|c|}{ DIM contrast ( $P$-value) } \\
\hline Linear & $* * *$ & $* * *$ & $* * *$ & $* * *$ & $* * *$ & $* * *$ \\
\hline Quadratic & $* * *$ & NS & $* * *$ & *** & NS & NS \\
\hline Cubic & $* * *$ & NS & $* * *$ & $* * *$ & NS & NS \\
\hline $\mathrm{RMSE}^{6}$ & 73 & 56 & 70 & 71 & 63 & 67 \\
\hline
\end{tabular}

${ }^{1}$ Significance (NS and asterisks) refers to the difference between intercept estimate and the expected 0.00 value.

${ }^{2}$ Significance (NS and asterisks) refers to the difference between slope estimate and the expected 1.00 value.

${ }^{3}$ Asterisks refer to the significance of the orthogonal contrasts between the traditional dairy system versus all the modern ones (in the line "Traditional"); among modern dairy systems, the farms not using total mixed diets versus those using it (in the line "Modern no TMR"); among farms using TMR between those adding water $\left(\mathrm{TMR}_{\mathrm{W}}\right)$ versus those adding silages $\left(\mathrm{TMR}_{\mathrm{S}}\right)$ to moisturize the diet (in the line "Modern $\mathrm{TMR}$ "). ${ }^{4}$ The variance of herd/date within dairy system, expressed as a ratio with total variance.

${ }^{5}$ Asterisks refer to the orthogonal contrast between primiparous and multiparous (in the line "1st"); between second calvers and third and more calvers (in the line "2nd"); between third calvers and fourth and more calvers (in the line "3rd"); between fourth calvers and cows with 5 or more calvings (in the line " 4 th").

${ }^{6} \mathrm{RMSE}=$ root mean square error.

${ }^{*} P<0.05 ;{ }^{* *} P<0.01$; ${ }^{* * *} P<0.001$. 
similar in the 2 breeds, even when their diets had very different roughage:concentrate ratios.

\section{Direct Prediction of EME Traits from Milk FTIR Spectra}

Some studies have been carried out on the prediction of EME traits from IR spectra of milk, and none is based on reference data obtained with the gold standard method. Although the most accurate and precise measurements are obtained with respiration chambers, the number of cows that can be tested is necessarily limited and the artificial environment is very different from that on commercial farms.

Dehareng et al. (2012) is the first attempt that we are aware of to predict EME traits from IR milk spectra. To predict $\mathrm{CH}_{4}$ emissions, they sampled air through a capillary tube situated between the cows' nostrils using $\mathrm{SF}_{6}$ released in the rumen as a tracer (Martin et al., 2008). Analyses were made of the $\mathrm{SF}_{6}$ and $\mathrm{CH}_{4}$ contents of 77 air samples, and of the FTIR spectra and $\mathrm{FA}_{\mathrm{GC}}$ profiles of 154 milk samples taken $1.5 \mathrm{~d}$ after air analysis from 11 Holstein cows (dMY: $19.7 \pm 5.1 \mathrm{~kg} / \mathrm{d}$ ) on 3 different diets. The $\mathrm{R}^{2}$ values of the direct-IR prediction equations, obtained from this preliminary study, were in the range of 0.68 to 0.72 with a corresponding root mean square error of 84 to $105 \mathrm{~g} / \mathrm{d}$ for $\mathrm{dCH}_{4}$, and in the range of 0.69 to 0.79 with an root mean square error of 5.00 to $6.22 \mathrm{~g} / \mathrm{kg}$ for $\mathrm{CH}_{4} / \mathrm{CM}$, although given the small number of diets, cows, and samples, these results should be treated with caution. It is worth noting that Dehareng et al. (2012) also analyzed the FA profiles of milk samples and obtained an $\mathrm{R}^{2}$ coefficient of the multiple correlation with $\mathrm{CH}_{4} / \mathrm{CM}$ (0.76) that was very similar to that obtained from the direct-IR validations.

In a later study by the same research group (Vanlierde et al., 2015) on a larger data set $\left(446 \mathrm{dCH}_{4}\right.$ measurements from 142 Jersey, Holstein, and Holstein-Jersey cows from Belgium and Ireland), again using the $\mathrm{SF}_{6}$ method, the direct-IR prediction equation was modified by incorporating DIM on the day of milk sampling using linear and quadratic Legendre polynomials. The reason for this was that if it had not been included in the prediction equation the results obtained using only FTIR spectra would not have reflected the expected pattern throughout lactation due to productive and metabolic modifications with advancing DIM (de Haas et al., 2011). The $\mathrm{R}^{2}$ of the $\mathrm{dCH}_{4-\mathrm{IR}}$ prediction equation was 0.75 , whereas the root mean square error was 63 $\mathrm{g} / \mathrm{d}$. The study reported only daily $\mathrm{CH}_{4}$ production, but a follow-up study on the genetic parameters of predicted EME traits also included $\mathrm{CH}_{4} / \mathrm{CM}$ (Kandel et al., 2017).
Shetty et al. (2017) recently completed a large experiment on 500 Danish Holstein cows on 1 experimental and 2 commercial farms. The reference values were obtained using "sniffers" placed within the automated milking stations, which produced 3,623 measures of $\mathrm{CH}_{4}: \mathrm{CO}_{2}$ ratios. Rather than estimating $\mathrm{dCH}_{4}$ using the flow of $\mathrm{SF}_{6}$ gas from the rumen, they estimated the cows' daily $\mathrm{CO}_{2}$ production from $\mathrm{BW}$, milk yield, and gestation age (Madsen et al., 2010), which provided 2,202 estimates of $\mathrm{dCH}_{4}$ production. Validation of the prediction equations based only on milk FTIR spectra obtained using partial least squares regression yielded $\mathrm{R}^{2}$ values of 0.21 for the $\mathrm{CH}_{4}: \mathrm{CO}_{2}$ ratio, and 0.13 for $\mathrm{dCH}_{4}$ (i.e., much lower than those obtained in this study), and the authors judged that prediction of EME traits using only FTIR spectra was not feasible. When they added information on dMY, herd, parity, DIM, and season to the spectra, the $\mathrm{R}^{2}$ values increased to 0.31 and 0.39 , respectively, but the contribution of the FTIR spectra was considered to be modest.

It is worth noting that in our study, where we did not include DIM or other information in the calibration equations, the reference data and 10 of the 13 directIR and indirect-IR predictions of the 5 EME traits exhibited a 3rd order pattern during lactation, with lower values in early lactation (Tables 3, 4, and 5), in accordance with theoretical expectations for these traits (de Haas et al., 2011). The only exceptions were $\mathrm{dCH}_{4-\mathrm{IR}}, \mathrm{dCH}_{4-\mathrm{IR} \text {-IR }}$, and $\mathrm{dCH}_{4-\mathrm{IR} \text {-FAIR }}$, where a linear decrease occurred over the course of lactation (Table 5). It is not surprising that the $\mathrm{R}^{2}$ values of our direct-IR prediction equations for $\mathrm{CH}_{4} / \mathrm{DMI}$ and $\mathrm{CH}_{4} / \mathrm{CM}(0.49$ and 0.57 , respectively) differ little from the equations of van Lingen et al. (2014), if we take into account the large number of herds and cows in our study, the variability in the systems sampled, and the year-round distribution of samplings.

\section{Informative Signals of Milk FTIR Spectra for Predicting EME Traits}

Regarding the calibration procedure, Vanlierde et al. (2015) used partial least squares (PLS) and preselected only 289 out of the 1,060 wavelengths of the entire spectral range $(2,966$ to $2,561,1,809$ to 1,720 , and 1,577 to $968 / \mathrm{cm}$ ) to reduce the size of the model and avoid noisy areas of the FTIR spectrum. For our study, we adopted a variable selection Bayesian model (BayesB), commonly used in genomic studies, and used the absorbances of all 1,060 waves without the need for wave preselection as the Bayesian model itself selects the most informative wavelengths for prediction (Ferragina et al., 2015). This also gave us an insight 
into the calibration equations for identifying the chemical bonds and compounds most involved in the predictions of EME traits or, at least, of the FA related to them. Moreover, this model has proven to be more effective than conventional PLS models for milk traits with modest determination coefficients of calibration (Ferragina et al., 2015).

Like Vanlierde et al. (2015), Shetty et al. (2017) also used 3 ranges of FTIR milk spectra (2,955 to 2,700, 1,820 to 1,705 , and 1,550 to 1,000 waves/cm), but having obtained VIP scores from recursive PLS analysis, they identified the most important areas of the spectrum for EME trait prediction.

Figures 1 and 2 allow us to clearly identify the more informative wavelengths of each predicted EME trait according to the Bayesian model we adopted, and to compare the equation coefficients with the Pearson correlations of each wavelength with the same trait. The first result that stands out is that the most informative wavelengths identified by the Bayesian model are seldom those with the highest simple correlations with the EME trait to be predicted, confirming our previous research (Ferragina et al., 2015).

Table 2 shows that of the 25 most informative FTIR signals for predicting EME traits ( 5 for each EME trait predicted), in our study we found 5 in areas of the spectrum that had not been considered in previous studies (Vanlierde et al., 2015). One signal was found in the near-IR section (SWIR, 3,978 waves $/ \mathrm{cm}$ ), 2 in the MIR section (MWIR, 2,539 and 2,442 waves/cm), and 2 very close to the 2 "water absorption" sections of the milk FTIR spectrum (2,982 and 1,701 waves/ $\mathrm{cm})$. These correspond to 2 of the 5 signals related to $\mathrm{dCH}_{4-\mathrm{IR}}$, 2 of the 5 signals of $\mathrm{CH}_{4} / \mathrm{CM}_{\mathrm{IR}}$, and 1 of the 5 signals of $\mathrm{CH}_{4} / \mathrm{CY}_{\mathrm{CURD}-\mathrm{IR}}$.

The data in Table 2 show that the areas of the milk FTIR spectrum that are informative for predicting EME traits are often also important for predicting other chemical or technological characteristics of milk.

The 5 signals related to $\mathrm{dCH}_{4}$ are also important for $\mathrm{dCY}_{\mathrm{CURD}}$ and $\mathrm{dCY} \mathrm{Y}_{\text {SOLIDS }}$, the protein content of milk (Lynch et al., 2006; Kaylegian et al., 2009), milk coagulation and curd firming patterns (Ferragina et al., 2017), and iso-palmitic and oleic acids. Four of the 5 signals listed in Table 2 for predicting $\mathrm{dCH}_{4}$ (excluding 2,442 waves $/ \mathrm{cm}$ ) are very close to the waves for the same trait and for predicting the $\mathrm{CH}_{4}: \mathrm{CO}_{2}$ ratio identified by Shetty et al. (2017) with a different methodology, whereas the 5 th signal $(2,442$ waves $/ \mathrm{cm})$ is in one of the areas of the spectrum these authors excluded from their analysis.

Methane yield, which reflects feedstuff fermentation in the rumen, is associated with the signals of the spectrum related to direct-IR prediction of almost all the informative FA included in the equation of van Lingen et al. (2014), which we used to estimate the reference data, and also of oleic acids, which were not included. Moreover, these signals are directly or closely related to prediction of milk fat and lactose (Lynch et al., 2006; Kaylegian et al., 2009) and to milk protein recovery in cheese (Ferragina et al., 2015).

The $3 \mathrm{CH}_{4}$ intensity traits expressed per unit of corrected milk, fresh cheese, and cheese solids are associated with the spectral signals related to informative FA, milk fat content (Kaylegian et al., 2009), and in particular and as expected, to cheese yields expressed as $\%$ of milk processed and daily production per cow, and to milk protein recovery in cheese and rennet coagulation time (Ferragina et al., 2015).

\section{Indirect Predictions of EME Traits from Milk FTIR Spectra}

An indirect use of the IR calibrations could be to predict informative FA to be used in estimating EME traits $\left(\mathrm{FA}_{\mathrm{IR}}\right)$. The ability of the direct-IR and indirectIR predictions to analyze and quantify the effects of the major sources of variation in the $\mathrm{CH}_{4} / \mathrm{DMI}$ and $\mathrm{CH}_{4} /$ $\mathrm{CM}$ traits were almost equivalent to each other and to the reference data (Table 3 ).

In the case of $\mathrm{CH}_{4} / \mathrm{CY}_{\mathrm{CURD}}$ and $\mathrm{CH}_{4} / \mathrm{CY}_{\text {SOLIDS}}$, an indirect use of the IR calibrations has been to predict $\mathrm{dCH}_{4-\mathrm{IR}}$ and $\mathrm{dCY}_{-\mathrm{IR}}$ and then to calculate their ratios. This indirect-IR method proved to be much less efficient than direct-IR predictions, and the reason for this may lie in the difficulty of predicting daily traits.

This is particularly evident in predicting $\mathrm{dCH}_{4}$, where neither direct-IR prediction nor IR prediction of dCMY multiplied by the direct or indirect predictions of $\mathrm{CH}_{4} / \mathrm{CM}$ were satisfactory compared with the reference method (Table 5). Daily $\mathrm{CH}_{4}$ production is a combination of a dimensional scaling factor, which depends on the cow's size, feed intake, and milk yield, and a more qualitative factor related to the relative production of $\mathrm{CH}_{4}$ per unit of feed ingested or milk produced. The difficulty in predicting the quantity of $\mathrm{CH}_{4}$ produced using only characteristics of the milk (FTIR spectra), and not the quantity, is evident, as Shetty et al. (2017) have also clearly shown. It is not surprising that much more satisfactory results were obtained when the dimensional aspect of $\mathrm{dCH}_{4}$ was represented by the measured dCMY value, and the qualitative aspect was represented by the direct and indirect predictions of $\mathrm{CH}_{4} / \mathrm{CM}$ (Table 5).

The reference data based on $\mathrm{FA}_{\mathrm{GC}}$ have been found to be heritable in this population (G. Bittante and A. Cecchinato, University of Padova, Legnaro, Italy, unpublished data). Direct-IR prediction of $\mathrm{dCH}_{4}$ has 
been put forward as the major trait for selecting cows with the aim of genetically improving the ecological footprint of the dairy sector, but the feasibility of genetic selection based on direct-IR predictions is highly controversial (Vanrobays et al., 2016; Shetty et al., 2017). Our results suggest that $\mathrm{dCH}_{4}$ calculated from measured dCMY or dCY and direct-IR or indirect-IR predictions of $\mathrm{CH}_{4}$ intensity per unit of milk or cheese is more accurate than direct-IR prediction. In any case, further research is needed to explore the feasibility of using EME traits predicted with different direct-IR and indirect-IR methods to genetically improve dairy cattle populations.

\section{CONCLUSIONS}

In this study, we examined the accuracy of EME traits predicted directly from milk FTIR spectra compared with reference data based on equations developed from a meta-analysis of the relationships between the EME traits and milk FA profiles analyzed by $\mathrm{GC}\left(\mathrm{FA}_{\mathrm{GC}}\right)$. Direct prediction of EME traits from milk FTIR spectra seems a viable option for estimating EME in the field. Possible alternatives, potentially more accurate, could be to combine daily milk yield with FTIR predictions to estimate daily $\mathrm{CH}_{4}$ production, or to use FTIR predictions to estimate informative milk FA proportions for use in estimating EME traits. Their application in genetic or genomic selection is appealing, but more detailed analysis of the genetic correlations between the reference and predicted data, and of the molecular basis of both, is required.

\section{ACKNOWLEDGMENTS}

The authors thank the Superbrown Consortium of Bolzano and Trento (Trento, Italy) for their support with sampling and recording, and M. Mele and G. Conte (Dipartimento di Scienze Agrarie, Alimentari, Agro-ambientali, Università di Pisa, Pisa, Italy) for their support in analyzing and discussing the detailed fatty acid profiles.

\section{REFERENCES}

Basarab, J. A., K. A. Beauchemin, V. S. Baron, K. H. Ominski, L. L. Guan, S. P. Miller, and J. J. Crowley. 2013. Reducing GHG emissions through genetic improvement for feed efficiency: Effects on economically important traits and enteric methane production. Animal 7:303-315.

Beauchemin, K. A., T. Coates, B. Farr, and S. M. McGinn. 2012 Technical note: Can the sulfur hexafluoride tracer gas technique be used to accurately measure enteric methane production from ruminally cannulated cattle? J. Anim. Sci. 90:2727-2732.

Bittante, G., and A. Cecchinato. 2013. Genetic analysis of the Fouriertransform infrared spectra of bovine milk with emphasis on indi- vidual wavelengths related to specific chemical bonds. J. Dairy Sci 96:5991-6006

Bittante, G., A. Cecchinato, and S. Schiavon. 2018. Dairy system, parity and lactation stage affect enteric methane production, yield, and intensity per kilogram of milk and cheese predicted from gas chromatography fatty acids. J. Dairy Sci. 101:1752-1766.

Cecchinato, A., M. De Marchi, M. Penasa, J. Casellas, S. Schiavon, and G. Bittante. 2012. Genetic analysis of beef fatty acid composition predicted by near-infrared spectroscopy. J. Anim. Sci. 90:429-438.

Chagunda, M. G. G., and T. Yan. 2011. Do methane measurements from a laser detector and an indirect open-circuit respiration calorimetric chamber agree sufficiently closely? Anim. Feed Sci. Technol. 165:8-14

Cipolat-Gotet, C., A. Cecchinato, M. De Marchi, and G. Bittante. 2013. Factors affecting variation of different measures of cheese yield and milk nutrient recovery from an individual model cheesemanufacturing process. J. Dairy Sci. 96:7952-7965.

CVB. 2008. CVB Table Booklet Feeding of Ruminants. CVB series no. 43. Centraal Veevoederbureau, Lelystad, the Netherlands.

de Haas, Y., M. Pszczola, H. Soyeurt, E. Wall, and J. Lassen. 2017. Invited review: Phenotypes to genetically reduce greenhouse gas emissions in dairying. J. Dairy Sci. 100:855-870.

de Haas, Y., J. J. Windig, M. P. L. Calus, J. Dijkstra, M. de Haan, A. Bannink, and R. F. Veerkamp. 2011. Genetic parameters for predicted methane production and potential for reducing enteric emissions through genomic selection. J. Dairy Sci. 94:6122-6134.

de los Campos, G., and P. Perez Rodriguez. 2015. BGLR: Bayesian Generalized Linear Regression. R package version 1.0.4. Accessed Sep. 20, 2017. http://CRAN.R-project.org/package=BGLR.

Dehareng, F., C. Delfosse, E. Froidmont, and H. Soyeurt. 2012. Potential use of milk mid-infrared spectra to predict individual methane emission of dairy cows. Animal 6:1694-1701.

Eskildsen, C. E., M. A. Rasmussen, S. B. Engelsen, L. B. Larsen, N A. Poulsen, and T. Skov. 2014. Quantification of individual fatty acids in bovine milk by infrared spectroscopy and chemometrics: Understanding predictions of highly collinear reference variables. J. Dairy Sci. 97:7940-7951.

Feng, S., A. L. Lock, and P. C. Garnsworthy. 2004. A rapid lipid separation method for determining fatty acid composition of milk. J. Dairy Sci. 87:3785-3788.

Ferragina, A., C. Cipolat-Gotet, A. Cecchinato, M. Pazzola, M. L. Dettori, G. M. Vacca, and G. Bittante. 2017. Prediction and repeatability of milk coagulation properties and curd-firming modeling parameters of ovine milk using Fourier-transform infrared spectroscopy and Bayesian models. J. Dairy Sci. 100:3526-3538.

Ferragina, A., G. de los Campos, A. I. Vazquez, A. Cecchinato, and G. Bittante. 2015. Bayesian regression models outperform partial least squares methods for predicting milk components and technological properties using infrared spectral data. J. Dairy Sci. 98:8133-8151.

Ferrand-Calmels, M., I. Palhière, M. Brochard, O. Leray, J. M. Astruc, M. R. Aurel, S. Barbey, F. Bouvier, P. Brunschwig, H. Caillat, M. Douguet, F. Faucon-Lahalle, M. Gelè, G. Thomas, J. M. Trommenshlager, and H. Larroque. 2014. Prediction of fatty acid profiles in cow, ewe, and goat milk by mid-infrared spectrometry. J. Dairy Sci. 97:17-35.

Fleming, A., F. S. Schenkel, J. Chen, F. Malchiodi, V. Bonfatti, R. A. Ali, B. Mallard, M. Corredig, and F. Miglior. 2017. Prediction of milk fatty acid content with mid-infrared spectroscopy in Canadian dairy cattle using differently distributed model development sets. J. Dairy Sci. 100:5073-5081.

Hammond, K. J., A. K. Jones, D. J. Humphries, L. A. Crompton, and C. K. Reynolds. 2016. Effects of diet forage source and neutral detergent fiber content on milk production of dairy cattle and methane emissions determined using GreenFeed and respiration chamber techniques. J. Dairy Sci. 99:7904-7917.

Hristov, A. N., J. Oh, F. Giallongo, T. Frederick, M. T. Harper, H Weeks, A. F. Branco, W. J. Price, P. J. Moate, M. H. Deighton, S. R. O. Williams, M. Kindermann, and S. Duval. 2016. Short communication: Comparison of the GreenFeed system with the sulfur 
hexafluoride tracer technique for measuring enteric methane emissions from dairy cows. J. Dairy Sci. 99:5461-5465.

ICAR. 2017. Guidelines for Milk Analysis. International Committee for Animal Recording, Rome, Italy.

Immig, I. 1996. The rumen and hindgut as source of ruminant methanogenesis. Environ. Monit. Assess. 42:57-72.

Kandel, P. B., M.-L. Vanrobays, A. Vanlierde, F. Dehareng, E. Froidmont, N. Gengler, and H. Soyeurt. 2017. Genetic parameters of mid-infrared methane predictions and their relationships with milk production traits in Holstein cattle. J. Dairy Sci. 100:5578-5591.

Kaylegian, K. E., J. M. Lynch, J. R. Fleming, and D. M. Barbano. 2009. Influence of fatty acid chain length and unsaturation on midinfrared milk analysis. J. Dairy Sci. 92:2485-2501.

Kelsey, J. A., B. A. Corl, R. J. Collier, and D. E. Bauman. 2003. The effect of breed, parity, and stage of lactation on conjugated linoleic acid (CLA) in milk fat from dairy cows. J. Dairy Sci. 86:2588-2597.

Lynch, J. M., D. M. Barbano, M. Schweisthal, and J. R. Fleming. 2006. Precalibration evaluation procedures for mid-infrared milk analyzers. J. Dairy Sci. 89:2761-2774.

Madsen, J., B. S. Bjerg, T. Hvelplund, M. R. Weisbjier, and P. Lund. 2010. Methane and carbon dioxide ratio in excreted air for quantification of the methane production from ruminants. Livest. Sci. 129:223-227.

Martin, C., J. Rouel, J. P. Jouany, M. Doreau, and Y. Chilliard. 2008. Methane output and diet digestibility in response to feeding dairy cows crude linseed, extruded linseed, or linseed oil. J. Anim. Sci. 86:2642-2650.

Maurice-Van Eijndhoven, M. H. T., H. Bovenhuis, H. Soyeurt, and M. P. L. Calus. 2013. Differences in milk fat composition predicted by mid-infrared spectrometry among dairy cattle breeds in the Netherlands. J. Dairy Sci. 96:2570-2582.

Mele, M., N. P. P. Macciotta, A. Cecchinato, G. Conte, S. Schiavon, and G. Bittante. 2016. Multivariate factor analysis of detailed milk fatty acid profile: Effects of dairy system, feeding, herd, parity, and stage of lactation. J. Dairy Sci. 99:9820-9833.

Mele, M., A. Serra, A. Buccioni, G. Conte, A. Pollicardo, and P. Secchiari. 2008. Effect of soybean oil supplementation on milk fatty acid composition from Saanen goats fed diets with different forage: concentrate ratios. Ital. J. Anim. Sci. 7:297-311.

Negussie, E., Y. de Haas, F. Dehareng, R. J. Dewhurst, J. Dijkstra, N. Gengler, D. P. Morgavi, H. Soyeurt, S. van Gastelen, T. Yan, and F. Biscarini. 2017. Invited review: Large-scale indirect measurements for enteric methane emissions in dairy cattle: A review of proxies and their potential for use in management and breeding decisions. J. Dairy Sci. 100:2433-2453.

Pegolo, S., A. Cecchinato, J. Casellas, G. Conte, M. Mele, S. Schiavon, and G. Bittante. 2016. Genetic and environmental relationships of detailed milk fatty acids profile determined by gas chromatography in Brown Swiss cows. J. Dairy Sci. 99:1315-1330.

Pegolo, S., C. Dadousis, N. Mach, Y. Ramayo-Caldas, M. Mele, G. Conte, S. Schiavon, G. Bittante, and A. Cecchinato. 2017. SNP co-association and network analyses identify E2F3, KDM5A and BACH2 as key regulators of the bovine milk fatty acid profile. Sci. Rep. https://doi.org/10.1038/s41598-017-17434-7.
Pryce, J. E., and M. J. Bell. 2017. The impact of genetic selection on greenhouse-gas emissions in Australian dairy cattle. Anim. Prod. Sci. 57:1451-1456.

Rutten, M. J. M., H. Bovenhuis, K. A. Hettinga, H. J. F. van Valenberg, and J. A. M. van Arendonk. 2009. Predicting bovine milk fat composition using infrared spectroscopy based on milk samples collected in winter and summer. J. Dairy Sci. 92:6202-6209.

Shetty, N., G. Difford, J. Lassen, P. Løvendahl, and A. J. Buitenhuis. 2017. Predicting methane emissions of lactating Danish Holstein cows using Fourier transform mid-infrared spectroscopy of milk. J. Dairy Sci. 100:9052-9060.

Soyeurt, H., P. Dardenne, A. Gillon, C. Croquet, S. Vanderick, P. Mayeres, C. Bertozzi, and N. Gengler. 2006. Variation in fatty acid contents of milk and milk fat within and across breeds. J. Dairy Sci. 89:4858-4865.

Soyeurt, H., F. Dehareng, N. Gengler, S. McParland, E. Wall, D. P. Berry, M. Coffey, and P. Dardenne. 2011. Mid-infrared prediction of bovine milk fatty acids across multiple breeds, production systems, and countries. J. Dairy Sci. 94:1657-1667.

Sturaro, E., E. Marchiori, G. Cocca, M. Penasa, M. Ramanzin, and G. Bittante. 2013. Dairy systems in mountainous areas: farm animal biodiversity, milk production and destination, and land use. Livest. Sci. 158:157-168.

van Gastelen, S., and J. Dijkstra. 2016. Prediction of methane emission from lactating dairy cows using milk fatty acids and mid-infrared spectroscopy. Mini review. J. Sci. Food Agric. 96:3963-3968.

van Lingen, H. J., L. A. Crompton, W. H. Hendriks, C. K. Reynolds, and J. Dijkstra. 2014. Meta-analysis of relationships between enteric methane yield and milk fatty acid profile in dairy cattle. J. Dairy Sci. 97:7115-7132.

Vanlierde, A., M.-L. Vanrobays, F. Dehareng, E. Froidmont, H. Soyeurt, S. McParland, and E. Lewis. 2015. Hot topic: Innovative lactation-stage-dependent prediction of methane emissions from milk mid-infrared spectra. J. Dairy Sci. 98:5740-5747.

Vanlierde, A., M.-L. Vanrobays, N. Gengler, P. Dardenne, E. Froidmont, H. Soyeurt, S. McParland, E. Lewis, M. H. Deighon, M. Mathot, and F. Dehareng. 2016. Milk mid-infrared spectra enable prediction of lactation-stage dependent methane emissions of dairy cattle within routine population-scale milk recording schemes. Anim. Prod. Sci. 56:258-264

Vanrobays, M.-L., C. Bastin, J. Vandenplas, H. Hammami, H. Soyeurt, A. Vanlierde, F. Dehareng, E. Froidmont, and N. Gengler. 2016. Changes throughout lactation in phenotypic and genetic correlations between methane emissions and milk fatty acid contents predicted from milk mid-infrared spectra. J. Dairy Sci. 99:7247-7260.

Wu, L., P. W. G. G. Koerkamp, and N. Ogink. 2018. Uncertainty assessment of the breath methane concentration method to determine methane production of dairy cows. J. Dairy Sci. 101:15541564.

Xue, B., T. Yan, C. F. Ferris, and C. S. Mayne. 2011. Milk production and energy efficiency of Holstein and Jersey-Holstein crossbred dairy cows offered diets containing grass silage. J. Dairy Sci. 94:1455-1464. 